\title{
Shaft Lengths and Shaft Development Types in the Vadose Zone of the Bakony Region (Transdanubian Mountains, Hungary)
}

\author{
Márton Veress* \\ Department of Geography, Eötvös Lóránd University, Szombathely, Hungary
}

\begin{abstract}
The potential and explored lengths of the shafts of the Bakony Region were studied. Shaft patterns were distinguished with the help of shaft maps and potential shaft lengths were calculated considering preforming geological structures and the thickness of the vadose zone. The average depth and average specific length of the explored shaft lengths were calculated in some areas of the Bakony Region. It can be established that potential shaft length depends on the thickness of the vadose zone, on the spatial position of the preforming geological structures and on the length compared to each other of the shaft parts that developed along them. The explored shaft lengths may exceed the potential shaft lengths since in addition to the above mentioned things, lengths depend on the type of the shaft pattern which is affected by the water-filled state of the shafts. In the Bakony Region there are some karst areas where the value of the explored average shaft depth and of the explored average specific length is large, while these values are smaller in other areas. The first group involves those areas where the characteristic features of the karst favour more frequent shaft floods. This flood results in paragenetic shaft development. The flood may originate from surface water, karst water and from both of the simultaneously. The chance of flood of surface origin depends of the morphology of the surface. There is a great chance of karst water flood if the thickness of the vadose zone is small, the rise of the karst water level is large, and the elevation difference of the shaft floor and the karst water level is small. In the various karst areas of the Bakony Region, shafts can be put into three types according to their genetics: Surface flood development type, karst water and surface flood development type and the tectonic development type. The type of shaft development is determined by the characteristics of the block bearing the karst area.
\end{abstract}

\section{Keywords}

Bakony Region, Vadose zone, Shaft, Paragenetic shaft development, Surface flood shaft development type, Karst water and surface flood shaft development type

\section{Introduction}

\section{Objective and shaft characteristics in the moun- tains}

The aim of this study is to classify the shafts of the Bakony Region from a genetic point of view considering potential and actual shaft lengths and shaft patterns and then to describe the development of these types. The knowledge of these may be significant in the above mentioned karst areas, but in other karsts too (for instance on glaciokarsts where this cave type is widespread) for speleologists dealing with cave exploration and for those studying shaft genetics and karst development.

Shaft length may be potential, actual, explored and specific length. By potential length we mean the length that can be determined by calculation, the length that a shaft can theoretically reach during its development (growth) in case of a given vadose zone thickness and a given preforming geological structure. The actual length is the current length of the shaft, while the explored length is the known length of the shaft. If shaft development takes place along the preforming structure in the whole expansion of the vadose zone, to which a shaft development of a suitable duration and intensity is necessary, the actual length of the shaft is identical with the potential shaft length. The estimation of actual cave lengths is not without antecedents. There were some efforts for the estimation of cave sizes (lengths) at inflow caves. Thus, based on the appearance period of the dye in the springs during the dye tracing procedure [1], and the stored amount of water

*Corresponding author: Márton Veress, Department of Geography, Eötvös Lóránd University, Szombathely, Hungary

Accepted: May 13, 2019

Published online: May 15, 2019

Citation: Veress M (2019) Shaft Lengths and Shaft Development Types in the Vadose Zone of the Bakony Region (Transdanubian Mountains, Hungary). J Soil Water Sci 3(1):54-74 
Citation: Veress M (2019) Shaft Lengths and Shaft Development Types in the Vadose Zone of the Bakony Region (Transdanubian Mountains, Hungary). J Soil Water Sci 3(1):54-74

Table 1: Specific lengths of some explored caves in the Bakony Region [43].

\begin{tabular}{|l|l|l|l|l|}
\hline The name of the cave & Occurrence site & Length (m) & Depth (m) & Specific length \\
\hline Alba Regia cave & Tési Plateau & 3600.00 & 200.20 & 17.98 \\
\hline Main branch of Alba Regia cave & Tési Plateau & 406.25 & 200.20 & 2.03 \\
\hline Csengő shaft & Tési Plateau & 230 & 133.9 & 1.72 \\
\hline Háromkürtő shaft & Tési Plateau & 360.00 & 105.00 & 3.43 \\
\hline Jubileum shaft & Tési Plateau & 223.00 & 121.00 & 1.84 \\
\hline Cave of Tábla Valley & Tési Plateau & 350.00 & 78.00 & 4.49 \\
\hline Gombás-pusztai cave (the shaft of its depression marked G-5/a) & Hárskút basin & 70.00 & 25.00 & 2.80 \\
\hline cave of Homód Valley (Ereszes shaft) & Hárskút basin & 28.00 & 16.00 & 1.75 \\
\hline Kisharaszti shaft & Hárskút basin & 20.00 & 12.00 & 1.67 \\
\hline Bujó-lik & Kab Hill & 208.00 & 39.50 & 5.27 \\
\hline Fenyér-hegy shaft & Kab Hill & 4.50 & 4.50 & 1.0 \\
\hline Öreg-Köves inflow cave & Kab Hill & 378.00 & 59.00 & 6.41 \\
\hline Kessler-Hubert cave & Keszthely Mountains & 2000 & 200 & 10.00 \\
\hline
\end{tabular}

[2]. The specific shaft length is the shaft length belonging to the 1-metre vertical depth growth which is the quotient of the total length and the depth and it can be potential, actual and explored specific length.

When studying the potential shaft length, the data of explored shaft length are available. According to these data, the specific explored length of the shafts in the Bakony Region that were involved in the study are very different (Table 1). Hereinafter, we are looking for an answer how some factors (the thickness of the vadose zone, the spatial position of the preforming geological structure, the structure of the shaft) influence various specific exploration lengths.

Cave development and cavity formation may happen in the vadose zone and the phreatic zone on karst. The caves of the vadose zone are the shafts, the vertical expansion of which is large, but their horizontal expansion is relatively small. From a morphological point of view, the caves of the vadose zone can be simple and stepped [3], according to a development environment, primary vadose caves, drawdown vadose caves and invasion vadose caves are distinguished [4]. In the phreatic zone, the cavities are horizontal or nearly horizontal and their pattern may extend from a straight to a zigzag development $[4,5]$.

The shafts can develop by dissolution or erosion [4]. The latter develop during the further development of already existing phreatic passages [4]. The shafts develop along surfaces which interrupt the continuity of rocks, at which the water film moving downwards the developing shaft walls becomes slowly saturated and preserves its solution capacity reaching a large depth [3]. The formation of shafts is promoted by open fractures [6] and the permanent, continuous water supply. Such a way of water supply may be for example the meltwater of glaciers [7], the meltwater of the snowfill of the shafts [8] and the meltwater of snow origin flowing onto the floor of temperate solution dolines [9].

\section{The geology of the Bakony Region}

The Bakony Region ( $4300 \mathrm{~km}^{2}$ ) which is constituted by the
Bakony Mountains $\left(2200 \mathrm{~km}^{2}\right)$ and the surrounding environs with a lower elevation. The Bakony Region is situated in the Carpathian Basin. A mantle plume developed under the Carpathian Basin which thinned out the lower crust and this resulted in isostatic subsidence and created a sialic basin [10]. The sialic basin separated into partial basins by further subsidence. Such partial basins (structures) also surround the Transdanubian Mountains that bear the Bakony Region: In NW the Little Hungarian Plain and in SE the Great Hungarian Plain. The mountains is part of the Transdanubian Mountains. It is a karstic mountains with the largest area in Hungary. It is a meso region which is separated into micro region groups called Northern Bakony, Southern Bakony, Balaton Uplands, Bakonyalja and the Keszthely Mountains. The Bakony Region is regarded as the uppermost, non-metamorphic member of the Austro-Alpine Nappe [11]. The Transdanubian Mountains (Alpaca Macrostructural Unit) got into its present position from a southern alpine surroundings with a NE shift by the time of Miocene $[10,12]$. The Bakony Mountains is a low block mountains (its highest mountains is the Kőris Mountain $704 \mathrm{~m}$ ). Its Triassic floor is limestone (Dachstein Formation) and mainly the main dolomite with a thickness exceeding $600 \mathrm{~m}$ (Main Dolomite Formation). The mountains have an asymmetric synclinal structure [11,13]. In its SE part, older (Silurian, Devonian and Permian) rocks crop out onto the surface, while in its NW part the Paleozoic rocks subsided into the depth. Neritic limestones developed in an archipelago environment in the axis of the synclinal after a Jurassic pelagic environment. The thickness of Cretaceous and Eocene limestones is some 10 metres and they may be interrupted with clay, marly limestone and with clayey coal beds [1416]. Karstification took place in the mountains several times: Thus, in the Upper Triassic [17], in the Jurassic [18] and in the Cretaceous [19]. During the tropical karstification of the late Cretaceous age the mountains was transformed into a tropical karstic peneplain [20].

During late Oligocene and early Miocene age, the peneplain was covered with delta gravel (Csatka Gravel Formation) [21]. Since the end of Cretaceous age the mountains 


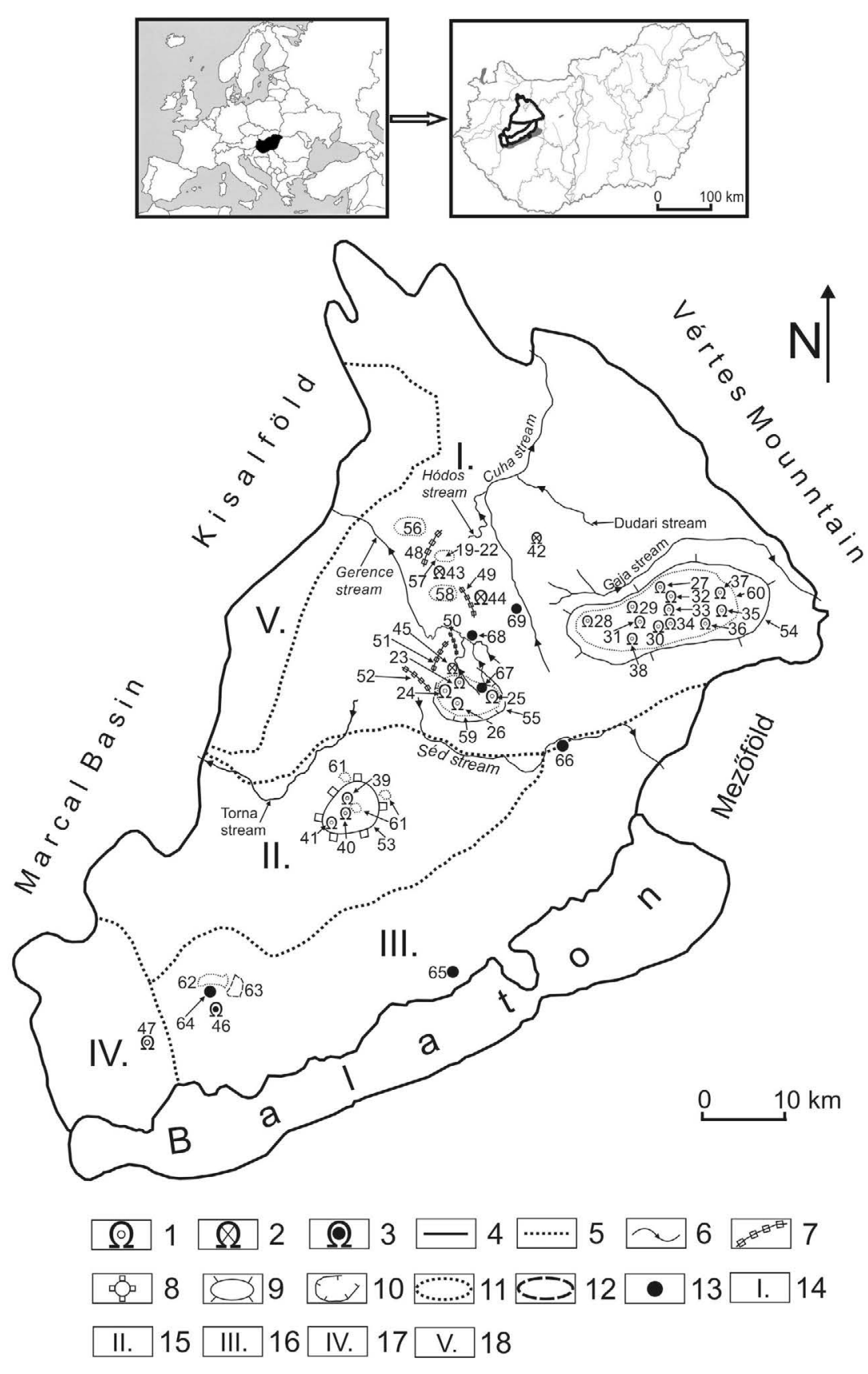

Figure 1: Karst features of the mountains; 1) Active shaft cave; 2) Inactive shaft cave; 3) Hydrothermal cave; 4) Boundary of the mountains; 5) Boundary of the microregion group; 6) Stream; 7) Block; 8) Block with basalt cap; 9) Plateau; 10) Basin; 11) Concealed karst area; 12) Bare karst area; 13) Settlement; 14) Northern Bakony; 15) Southern Bakony; 16) Balaton Uplands; 17) Keszthely Mountains; 18) Bakonyalja; 19) The shaft of the depression marked 1 of the Eleven-Förtés doline group 1 ; 20) The shaft of the depression marked 2 of the Eleven-Förtési doline group; 21) The shaft of the depression marked 7 of the Eleven-Förtés doline group; 22) The shaft of Dózeros depression; 23) Kisharaszt shaft (the shaft of the doline marked Gy-12); 24) The shaft of the doline marked G-5 25) The shaft of the depression marked $\mathrm{H}-1$; 26) The cave of Homód Valley (the shaft of the depression marked Ho-1); 27) Alba Regia cave (the shaft of the depression marked I-44); 28) Csengő shaft (the shaft of the depression marked I-110); 29) Egérfogó shaft (the shaft of the depression marked I-66/b); 30) Csillag shaft (the shaft of the depression marked I-102); 31) Háromkürtő shaft (the shaft of the depression marked I-12); 32) Cave of Tábla Valley (the shaft of the depression marked I-31) 33) Jubileum shaft (the shaft of the depression marked I-29); 34) Csipkés shaft (the shaft of the depression marked I-28); 35) Hétház shaft (the shaft of the depression marked I-33); 36) The shaft of the depression marked I-14; 37) The shaft of the depression marked I-27; 38) Kánkút shaft (the shaft of the depression marked I-152); 39) The shaft of Öreg-köves ponor 40) Bújó-lik; 41) Fenyér-hegy shaft; 42) Cseresi shaft; 43) Ördög-lik of Köris Hill; 44) Kis Pénz-lik and Nagy Pénz-lik; 45) Zsivány cave of Gyenespuszta; 46) Cave system of Tapolca; 47) Kessler Huber cave; 48) Kőris Hill; 49) Som Hill; 50) Égett Hill; 51) Mester-Hajag; 52) Középső-Hajag; 53) Kab Hill; 54) Tési Plateau; 55) Hárskút basin, Concealed karst areas; 56) The environs of Márvány Valley; 57) Eleven-Förtés doline group; 58) The area between Som Hill and Száraz-Gerence Valley; 59) Hárskút basin; 60) Tési Plateau; 61) The environs of Kab Hill; 62) Tapolca karst (its concealed karst part); 63) Tapolca karst (its bare karst part); 64) Tapolca; 65) Dörgicse; 66) Kádárta; 67) Hárskút; 68) Pénzesgyőr; 69) Zirc. 
Citation: Veress M (2019) Shaft Lengths and Shaft Development Types in the Vadose Zone of the Bakony Region (Transdanubian Mountains, Hungary). J Soil Water Sci 3(1):54-74

have been dissected by blocks. As a result of the oscillation movement of the blocks, the mountains is built up of adjacent blocks with various geomorphic evolution, different degree of uncoveredness and different elevation [22]. Blocks of lower position (intermountain basins and grabens) occur between more elevated blocks. Some elevated blocks may be dissected by epigenetic-antecedent gorges with cave-openings of phreatic origin [23].

Because of the various elevation of the blocks, the gravel cover was partially or completely destroyed in their area. The gravel cover or directly the calcareous surface became overlain by loess.

In the area of some blocks of the Southern Bakony, Pliocene basaltic volcanism took place [24]. The basalt (Tapolca Basalt Formation) constitutes basalt covers, which is the most widespread on Kab Mountain and here it contributes to karstification.

\section{The characteristics of the karst of the Bakony Region}

According to the coveredness of the karst, Gvozdetskiy [25] distinguished bare karst, soil-covered karst, covered karst and buried karst. This latter is a karst where no karstification occurs because of the large thickness of the cover. Hevesi [26] differentiated two varieties of covered karst: Cryptokarst (the cover is impermeable) and concealed karst (the cover is permeable).

Bare karst, soil-covered karst, concealed karst, cryptokarst and buried karst also occur in a mosaical expansion in the mountains. This can be attributed to the fact that the cover did not become denuded or it was destroyed to a various extent from their blocks of various geomorphic evolution and expansion. The areas of bare karst and soil-covered karst do not have a significant expansion. A cryptokarst and allogenic karst, mixed allogenic-autogenic karst is the basalt-covered terrain of Kab Hill where karstification has intensive, particular and unique features [27-29]. A cryptokarst is the inner part of the basalt cover where the basalt thins out, however where limestone crops out (at the margin of the basalt cover and at some sites inside) it is of mixed allogenic-autogenic type.

In the mountains, concealed karst has the largest (most frequent) expansion and it is the most characteristic. Concealed karst develops at sites where the cover is constituted by loess, clay, clayey sediment and their varieties with limestone debris [30-32]. Their most significant concealed karst areas are Tési Plateau, Kab Hill (terrains exempt from basalt cover), the environs of Márvány valley, the area between Som Hill and Száraz-Gerence valley, Hárskút basin (Figure 1) and the block built up of Middle Cretaceous limestones (Zirc Limestone Formation) (Mester-Hajag, Égett Hill). The above mentioned bear 535 out of 691 subsidence dolines of the mountains.

On concealed karst its surface karst features are subsidence dolines (mainly suffosion dolines), on the cryptokarst of basalt cover, caprock dolines and at the margin of the basalt cover, ponors. On the soil-covered karst at the margin of the mountains (Tapolca karst), some solution dolines and collapse dolines also occur. Karren are represented by subsoil karren for example near Dörgicse, but smaller karren features occur on bare karst, on dolomite (Kádárta).

The karst water of the mountains can be classified as main karst water and karst water storeys. The main karst water (it is mainly stored by the main dolomite) is uniform and extends to the whole area of the Transdanubian Mountains. The karst water storeys of the mountains developed at local impermeable beds above the main karst water which occur in larger and smaller development at different elevations. At the beginning of the $20^{\text {th }}$ century, preceding the artificial lowering of karst water level, the main karst water level was between 117-120 $\mathrm{m}$ at the margin of the mountains based on the elevation data of karst springs and karst moors at the margin of the mountains (at the northern margin of the Northern Bakony it was $140-180 \mathrm{~m}$, while it rose above $200 \mathrm{~m}$ at the south-eastern part of the mountains) [33-35]. Since the karst water level rises towards the inner part of the mountains, the reconstructed karst water level reached a maximum elevation of $290 \mathrm{~m}$ [36], and 260-280 m [37]. The fluctuation of karst water level and thus, the thickness of the epiphreatic zone may be significant. According to Böcker's data [38] it can exceed 100 m (near Hárskút). A karst water storey (high karst water) developed in the Cretaceous and Eocene limestone blocks surrounding Pénzesgyőr (for example Mester-Hajag), and on Kab Hill. Based on the data of karst springs, the karst water level may be at an altitude of $360-480 \mathrm{~m}$ in the Middle Cretaceous limestone blocks surrounding Pénzesgyőr (Mester-Hajag, Égett Hill). Its elevation alternates between the above mentioned values depending on the elevation of the bearing block.

The caves of the Bakony Region may have developed in a vadose or phreatic environment. The latter are predominantly relict caves that became exposed during valley down cutting $[23,29]$ but spring caves which developed at emergence sites also occur (caves under the town of Tapolca). The shafts of the vadose zone are the deepest caves of the mountains, but the longest can also be found among them except the cave system under the town of Tapolca. The number of explored caves (including inactive caves) in the mountains is more than 100.

The shafts are of dissolution origin, the role of erosion is subordinate in their development. This is proved by the solution depressions of shaft walls, the ridges left behind dissolution, prepared fossils, half tubes or blind shafts [29]. Their erosional development was not favoured by the presence of loess and the lack of gravel in their environment. The shafts occur in three kinds of morphological environments which are the following.

- They are situated below subsidence dolines thus, in a concealed karst environment [29]. This environment is the most common in the mountains. Such shafts can be found for example on the Tési Plateau and in the Hárskút basin.

- They occur under ponors. In this case the development environment is mixed allogenic-autogenic karst [28]. Such shafts are found on Kab Hill. The erosional effect is small in 


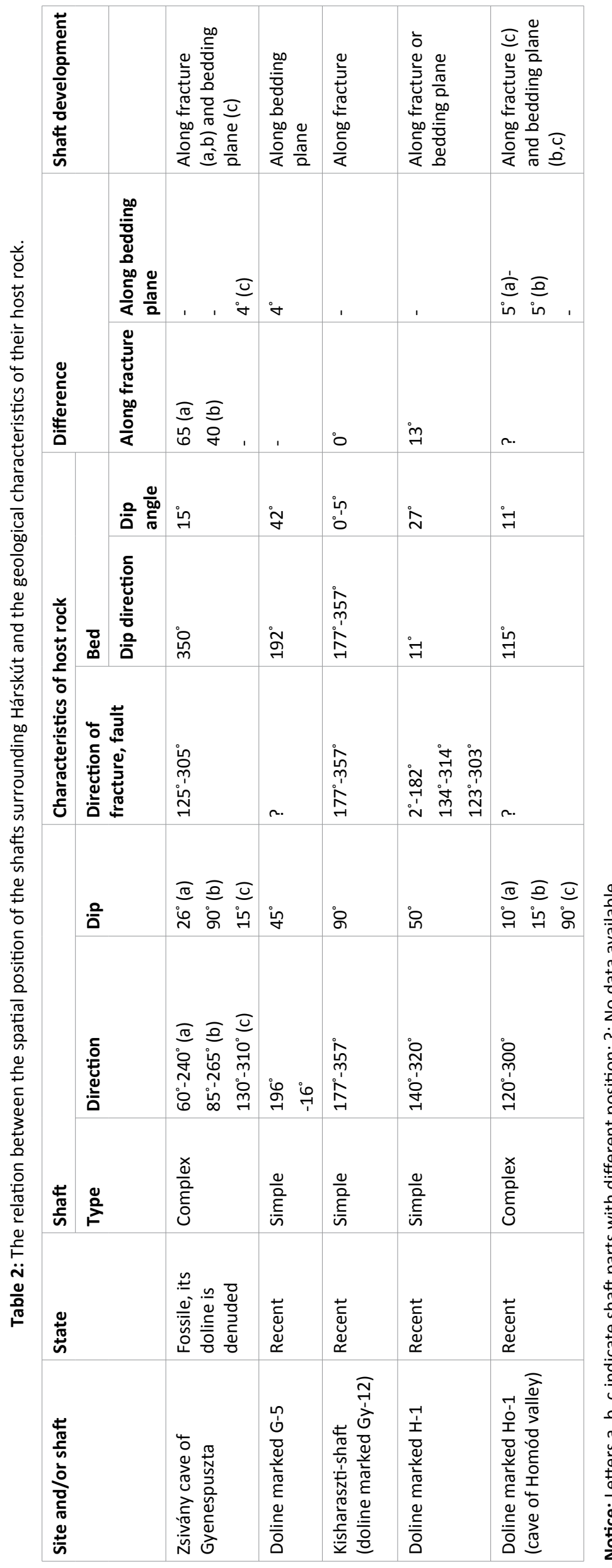




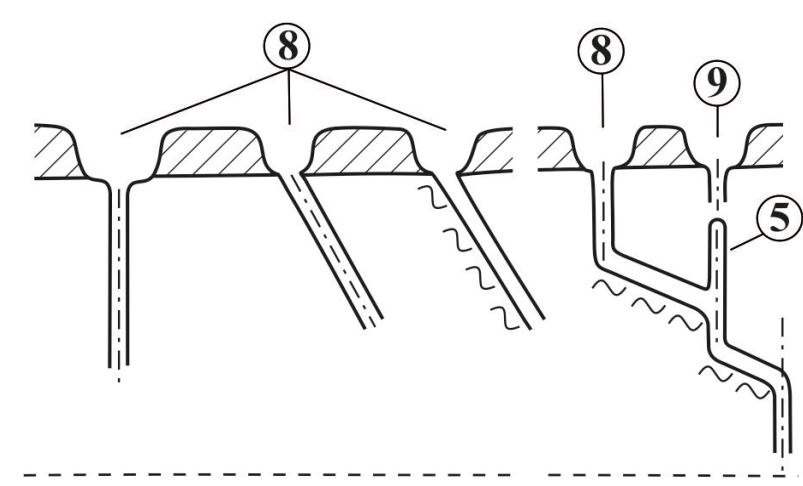

$\mathbf{a}$

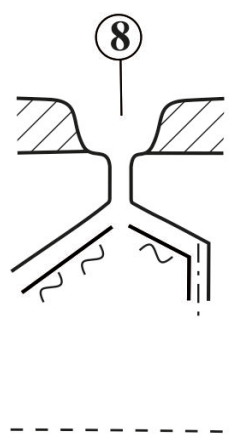

d

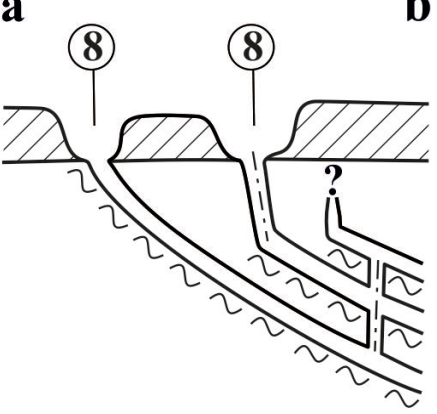

e

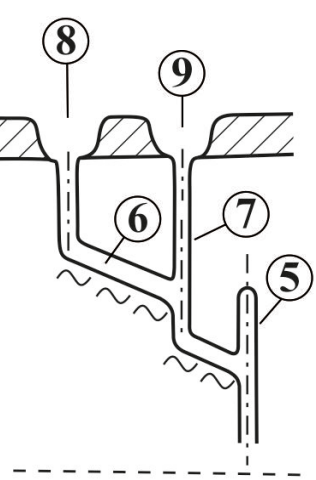

C

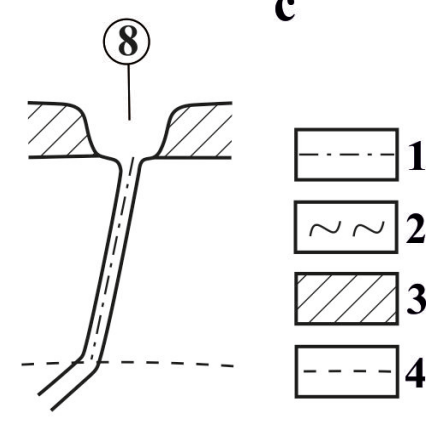

f

Figure 2: Shaft types; a) Simple shaft; b) Complex shaft; c) Shaft system; d) Bifurcating shaft; e) Storeyed shaft; f) Shaft with a phreatic passage part; 1) Fracture; 2) Bedding plane; 3) Cover (loess); 4) Karst water level; 5) Paragenetic blind shaft; 6) Main shaft; 7) Tributary shaft; 8) Main dolin; 9) Tributary doline.

case of these shafts too because of the low inclination of the surface of the basalt cover and the lack of gravel.

-The shaft are below former ponors. In this case the development environment of the shaft was mixed allogenicautogenic karst but today it is concealed karst. The shaft was formed under a ponor (now a subsidence doline). Such shafts may occur on Tési Plateau [23]. On Tési Plateau the gravel cover is absent, but its former presence is referred to by the gravel pieces occurring in some depressions and shafts. In case of some shafts, as for example at Alba Regia cave an erosional effect can also be detected [39].

According to our measurements and the analysis of the shaft maps $[40,41]$ the shafts of the mountains developed along fractures (fault) and/or bedding planes (Table 2). Shafts are built up of various shaft element thus, main shaft, tributary shaft and blind shaft. The main shaft is the longer shaft element of the shaft. The tributary shaft is the shorter element of the shaft which reaches the surface though. The blind shaft is a shaft element that does not reach the surface. By the combination of various shaft elements, different shaft structures may develop. The shaft structure preformed primarily by the geological structure may be the following (Figure 2).

- Simple shaft which developed along fracture (fault) or bedding plane. A simple shaft is the shaft of the subsidence doline marked G-5/a (Figure 3A) and the Csillag shaft (Figure 3B).

- Storeyed shaft some parts of which were formed along the bedding planes of beds situated above each other (the shafts are not necessarily situated above each other), but they coalesced. Such a storeyed shaft is for example the AlbaRegia cave (the shaft of the depression marked I-44, Figure 4).

- A complex shaft is a shaft some sections of which developed along fractures (faults), while its other sections were formed along bedding planes. The latter sections connect those that developed along fractures. In case of this type, blind shafts are common. A complex shaft is the cave of Homód Valley (the shaft of the depression marked Ho1, Figure 5A), a Gyenespusztai-Zsivány cave, Egérfogó cave (Figure 5C, the shaft of the depression marked I-66/b), Csengö shaft (the shaft of the depression marked I-110, Figure 5B).

- The shaft system has a main shaft and tributary shafts. The tributary shafts are connected to the main shaft. A shaft system is the Háromkürtő shaft (the shaft of the depression marked 1-12, Figure 6), Kisharaszti shaft (the shaft of the subsidence doline marked Gy-12).

- In case of a branching shaft, the bifurcating shaft creates a bunchy system below the karstic depression. In case of this type, main shafts, tributary shafts and blind shafts also occur. Such a shaft is for example the shaft of Öregköves ponor (Figure 7B) [29] and the cave of Tábla Valley (Figure 7A).

- A shaft develops with a phreatic passage part if the shaft of the vadose zone connect onto or to the phreatic passage that is situated below it. Such a shaft is the Kessler Hubert cave in the Keszthelyi Mountains [42]. 
Citation: Veress M (2019) Shaft Lengths and Shaft Development Types in the Vadose Zone of the Bakony Region (Transdanubian Mountains, Hungary). J Soil Water Sci 3(1):54-74

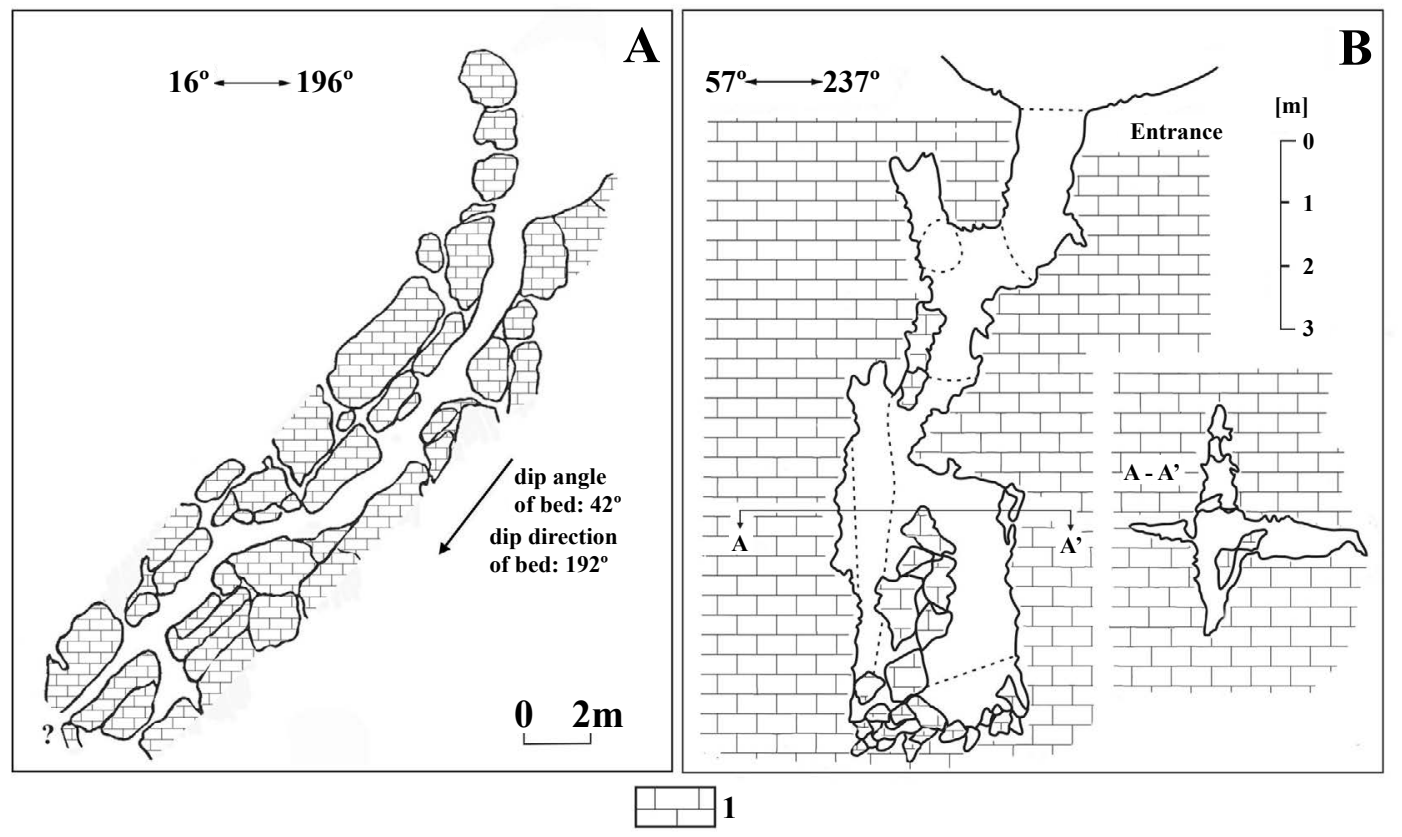

Figure 3: Simple shafts: Shaft that developed along bedding plane A) The shaft of the doline marked G-5, shaft that developed along fracture [23]; B) Csillag shaft, [43]; 1) Limestone.
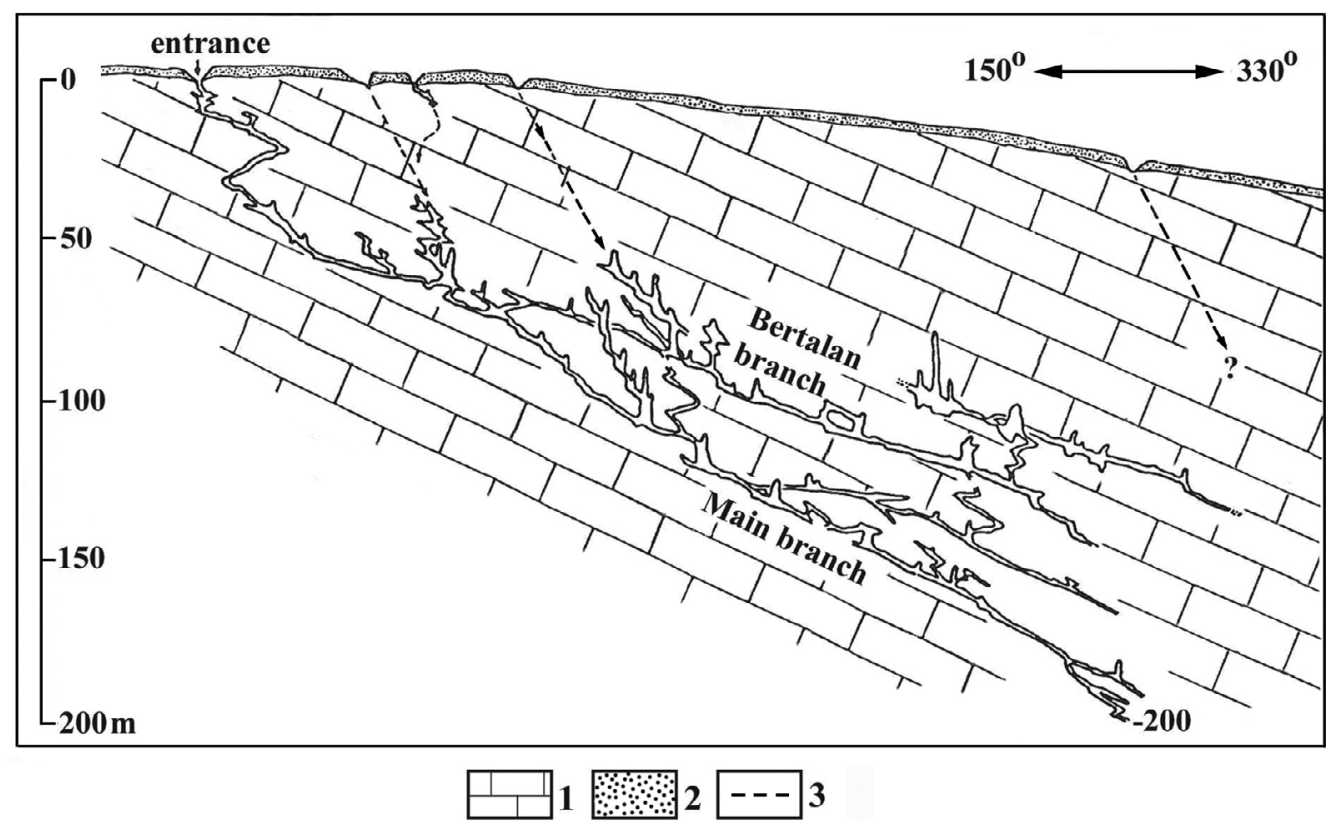

Figure 4: Storeyed shaft: Alba Regia cave [41]; 1) Limestone; 2) Cover; 3) Fracture.

The depressions bearing the shafts become truncated with the denudation of the superficial deposit bearing them $[23,29]$. In this case the shafts are transformed into destroying, senile features. Such a feature is for example the Gyenespusztai-Zsivány cave (Hárskút basin), Ördög-lik of Kőris block, Cseresi shaft (near Zirc), as well as Nagy Pénz-lik and Kis Pénz-lik (Som Hill). The inactive shafts became filled to a large degree therefore, they were ignored when calculating specific lengths.

\section{Method}

The potential shaft length is equal to the thickness of the vadose zone if the shaft developed along a preforming structure of vertical position and if the development of the shaft may happen until the karst water level, while if the development surface is not vertical, it can also be larger than that. Its value can be calculated in the following way in case of a shaft development surface different from a vertical position since in this case the shaft and the vertical straight line drawn from its entrance, and the horizontal line drawn between the shaft floor and the vertical straight line forms a rectangle 
Citation: Veress M (2019) Shaft Lengths and Shaft Development Types in the Vadose Zone of the Bakony Region (Transdanubian Mountains, Hungary). J Soil Water Sci 3(1):54-74

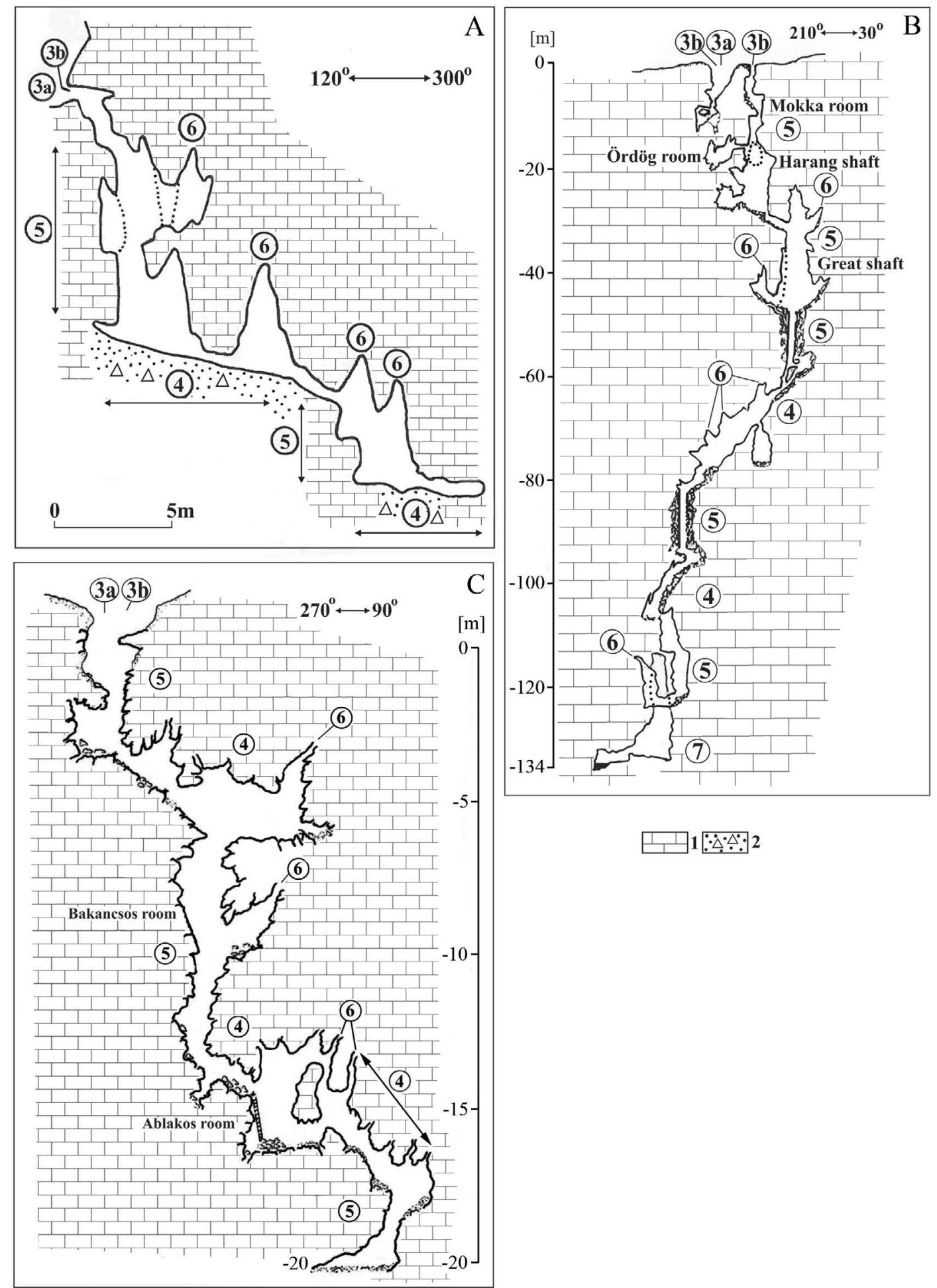

Figure 5: Complex shafts: the cave of Homód Valley; A) Csengő shaft [23]; B) Egérfogó cave [43]; C) [43]; 1) Host rock; 2) Washed-in soil, debris; 3a) Subsidence doline; 3b) Entrance; 4) Section that developed along bedding plane; 5) Section that developed along fracture; 6) Paragenetic blind shaft; 7) Siphon.

triangle (Figurg $8 \mathrm{a})$ :

$$
\begin{aligned}
& \sin \alpha=\frac{h}{L} \\
& L=\frac{h}{\sin \alpha}
\end{aligned}
$$

where $L$ is the potential shaft length,

$h$ is the thickness of the vadose zone,

$\alpha$ is the inclination of the fracture (fault) or bed along which the shaft developed. 


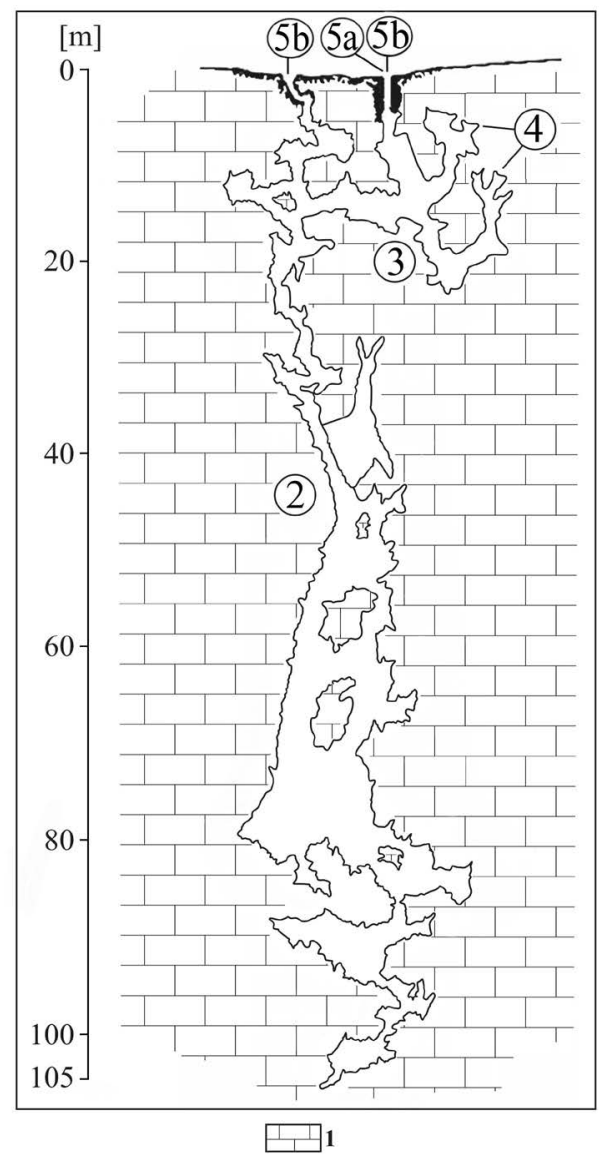

Figure 6: Shaft system (Háromkürtő shaft) [43]; 1) Host rock; 2) Main shaft; 3) Tributary shaft; 4) Paragenetic blind shaft; 5a) Subsidence doline; 5b) Entrance.
The thickness of the vadose zone (Figure 9) depends on the surface elevation of the block bearing the shaft and on the elevation of the karst water level. The expansion of the vadose zone $(h)$ can be given if we take the elevation difference between the block surface bearing the shaft entrance and the base level of erosion of the mountains (karst spring at the margin of the mountains), which we call the vadose zone of the mountains $\left(h_{1}\right)$. It can also be given in a way that we compare the block surface elevation to the main karst water level situated in the block. This is the local vadose zone $\left(h_{2}\right)$. Finally, where there is a karst water storey in the block (because of the intercalated non-karstic beds), its value can be calculated by elevation difference between the elevation of the block surface and the level of the karst water level, which we call a vadose zone above the karst water storey $\left(h_{3}\right)$. Since the majority of shafts does probably not reach the margin of the mountains (except they are situated very close to it) its value depends rather on the elevation of the karst water level that developed in the bearing block $\left(h_{2}\right)$. Thus, for example in case of the most elevated doline group of the mountains (Eleven-Förtés doline group) the value of $h_{1}$ is $535-495 \mathrm{~m}$, since the elevation of the doline group is 675 $\mathrm{m}$ and in its vicinity, in the northern part of the mountains, the emergence of the karst water level is 140-180 $\mathrm{m}$ [33]. However, as compared to the karst water level below the block, where the karst water level is $230 \mathrm{~m} \mathrm{[36]} \mathrm{its} \mathrm{value}\left(h_{2}\right)$ is smaller, $445 \mathrm{~m}$. It is probably that in the mountains, $h_{2}$ values are relevant. We obtained the main karst water level data being necessary to the determination of $h_{2}$ values by reading the elevation values (contour lines) giving the reconstructed karst water surface that can be read from the karst water level map of the Transdanubian Mountains [36]. We took 500 $\mathrm{m}$ as the value of the maximum local vadose zone thickness.
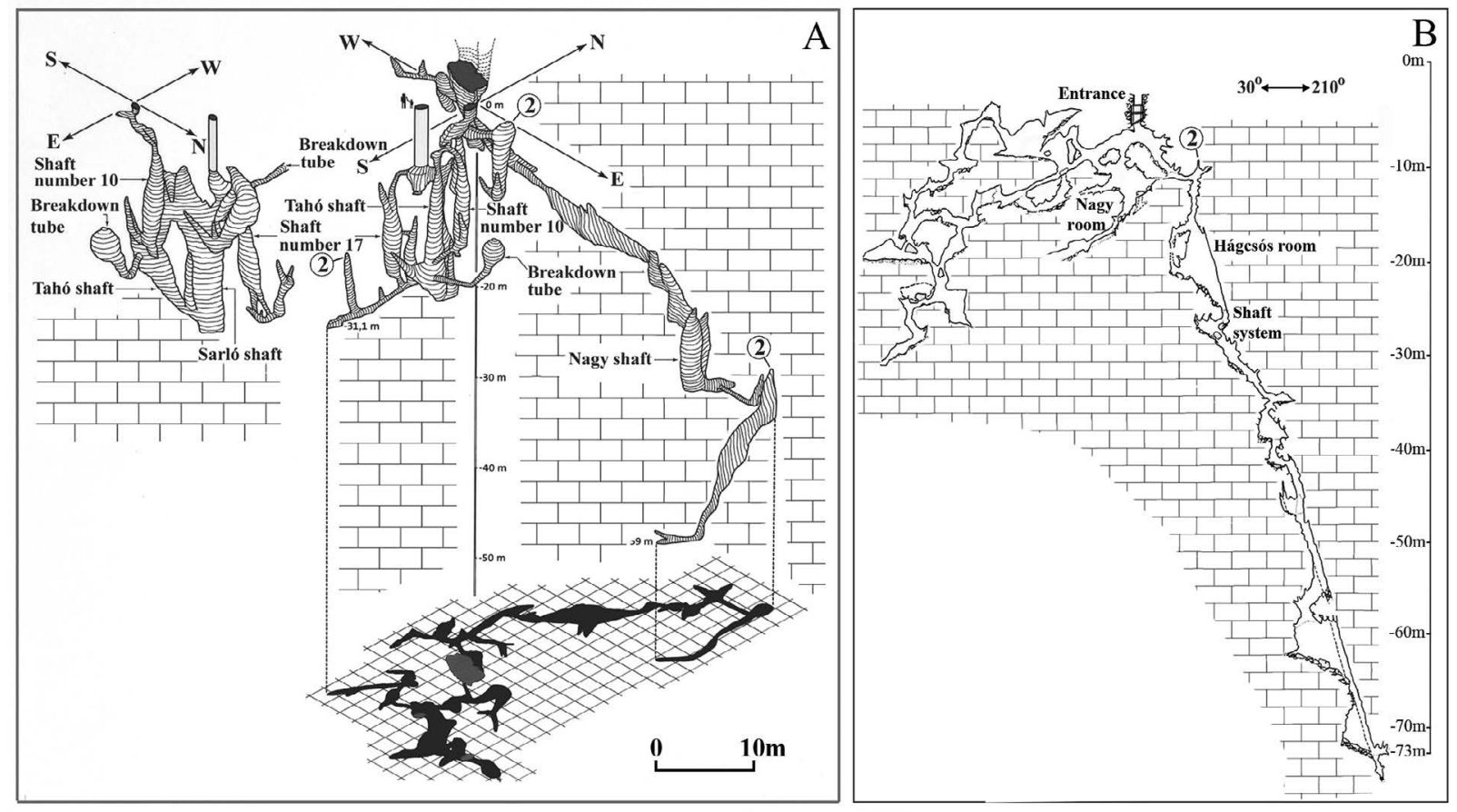

11

Figure 7: Bifurcating shaft: (cave of the Öreg-Köves ponor; A) The cave of Tábla Valley [29]; B) [43]; 1) Host rock; 2) Blind shaft. 


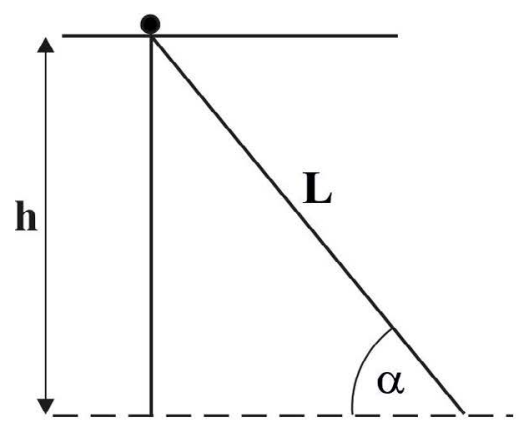

d

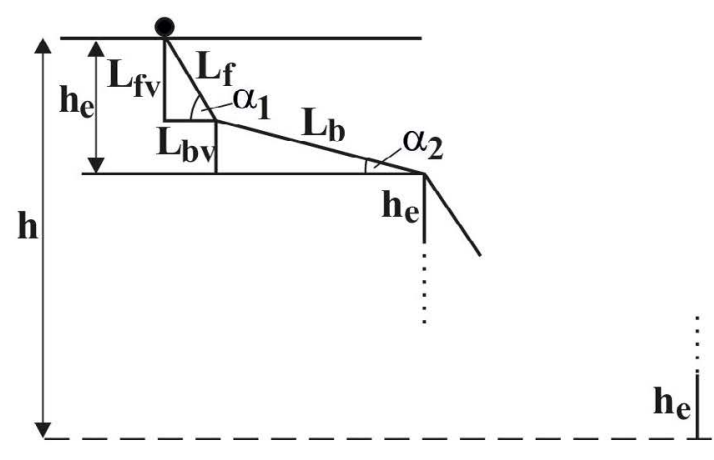

C
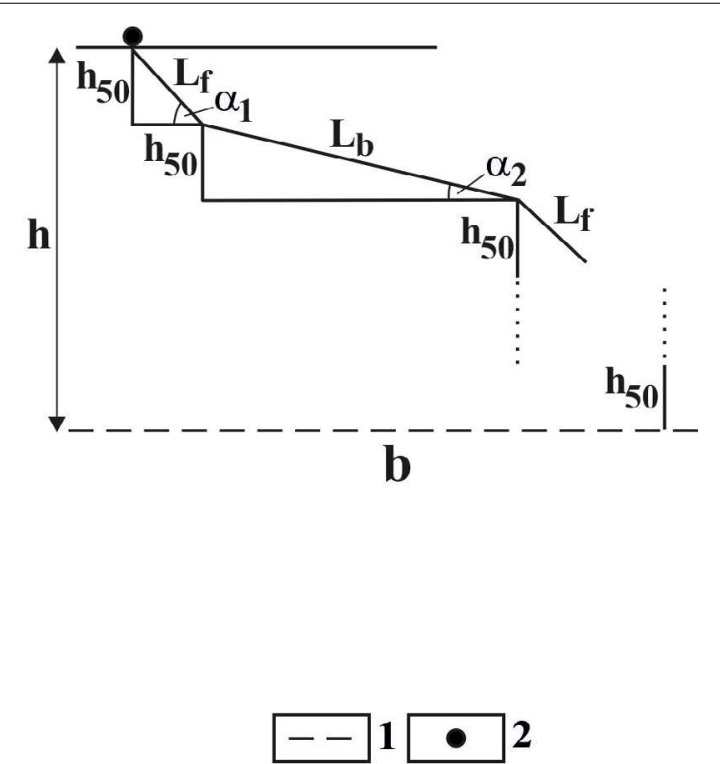

Figure 8: Calculation of potential shaft lengths; 1) Karst water level; 2) Karstic depression; h: Vadose zone, L: Shaft length; $\alpha$ : Shaft inclination; $L_{t}$ : A shaft section that developed along fracture in case of a rock thickness of $50 \mathrm{~m}$; $L_{r}$ : Shaft section that developed along bedding plane in case of a rock thickness of $50 \mathrm{~m} ; \alpha_{1}$ : Inclination of a shaft section that developed along fracture; $\alpha_{2}$ : Inclination of a shaft section that developed along bedding plane; $L_{t v}$ : Vertical projection of a shaft section that developed along fracture; $L_{r v}:$ Vertical projection of a shaft section that developed along bedding plane; $h_{e}$ : Sum of vertical projections, a) Potential shaft length of a simple shaft in case of a complete vadose zone, b) Potential shaft length of a complex shaft in case of a given vadose zone and a thickness of 50-50 $\mathrm{m}, \mathrm{c}$ ) Potential shaft length of a complex shaft belonging to a given vadose zone in case of sections along a given fracture and a given bedding plane.

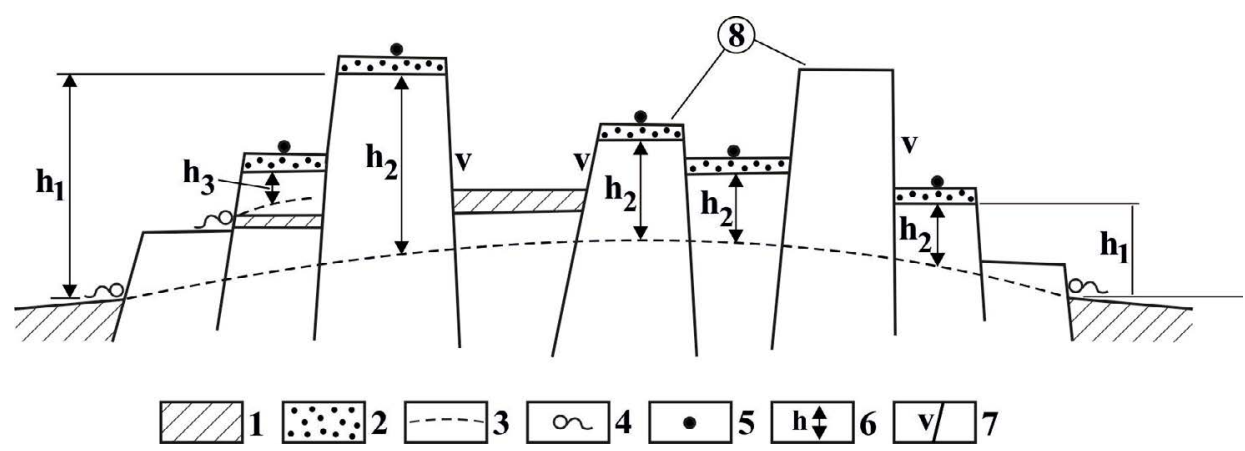

Figure 9: Varieties of vadose zone thickness in the mountains; 1) Non-karstic impermeable (partly impermeable) rock; 2) Permeable cover (loess); 3 ) Karst water level; 4$)$ Karst spring; 5$)$ Karstic depression; 6$)$ vadose zone $\left(h_{1}\right.$ : The vadose zone of the mountains, $h_{2}$ : Local vadose zone, $\mathrm{h}_{3}$ : Vadose zone above karst water storey); 7) Fault; 8) Block.

However, considering that the majority of the dolines is situated much lower with a shift of $100 \mathrm{~m}$ we also calculated $h_{2}$ with values of $400,300,200$ and $100 \mathrm{~m}$.

Both according to geological maps and our measurements, bed inclinations are not large in the mountains. (The largest measured dip was $42^{\circ}$, but based on the data of the maps inclinations of $10^{\circ}-20^{\circ}$ are the most characteristic). Therefore with a shift of $10^{\circ}$ and with bed dips of $10^{\circ}, 20^{\circ}, 30^{\circ}$ and $40^{\circ}$ we calculated shaft lengths that developed along bedding planes. According to geological maps, dip angles of fractures (faults) occur between $30^{\circ}$ and 90 . Consequently, shaft lengths along fractures (faults) were calculated considering dip angles of $30^{\circ}, 40^{\circ}, 50^{\circ}, 60^{\circ}, 70^{\circ}, 80^{\circ}$ and $90^{\circ}$.

Calculations were made to simple shaft lengths which develop in case of vadose zone thicknesses between 100 $\mathrm{m}$ and $500 \mathrm{~m}$, along the bedding planes of beds with an inclination of $10^{\circ}-40^{\circ}$ and along fractures (faults) with a dip of $30^{\circ}-90^{\circ}$ (Table 3 ). The length of complex shafts were given to vadose zone thicknesses between $100 \mathrm{~m}$ and $500 \mathrm{~m}$ in a way that we arbitrarily calculated the length of the shafts that 
Citation: Veress M (2019) Shaft Lengths and Shaft Development Types in the Vadose Zone of the Bakony Region (Transdanubian Mountains, Hungary). J Soil Water Sci 3(1):54-74

Table 3: Potential shaft lengths of simple shafts in case of a vadose zone with various thickness.

\begin{tabular}{|c|c|c|c|c|c|c|c|c|c|c|c|}
\hline \multirow[t]{2}{*}{$\alpha_{1}$} & \multirow[t]{2}{*}{$\alpha_{2}$} & $H(m)$ & f.a.h. & $H(m)$ & f.a.h. & $H(m)$ & f.a.h. & $H(m)$ & f.a.h. & $H(m)$ & f.a.h. \\
\hline & & 100 & & 200 & & 300 & & 400 & & 500 & \\
\hline- & $0^{\circ}$ & - & & - & & - & & - & & - & \\
\hline- & $10^{\circ}$ & 588.23 & 5.88 & 1176.47 & 5.88 & 1764.70 & 5.88 & 2352.94 & 5.88 & 2941.18 & 5.88 \\
\hline- & $20^{\circ}$ & 294.11 & 2.94 & 588.23 & 2.94 & 882.35 & 2.94 & 1176.47 & 2.94 & 1470.59 & 2.94 \\
\hline $30^{\circ}\left(60^{\circ}\right)$ & $30^{\circ}$ & 200.00 & 2.00 & 400.00 & 2.00 & 600.00 & 2.00 & 800.00 & 2.00 & 1000.00 & 2.00 \\
\hline $40^{\circ}\left(50^{\circ}\right)$ & $40^{\circ}$ & 156.25 & 1.56 & 312.5 & 1.56 & 468.75 & 1.56 & 625.00 & 1.56 & 781.25 & 1.56 \\
\hline $50^{\circ}\left(60^{\circ}\right)$ & & 129.87 & 1.30 & 259.74 & 1.30 & 389.61 & 1.30 & 519.48 & 1.30 & 649.35 & 1.30 \\
\hline $60^{\circ}\left(30^{\circ}\right)$ & & 114.94 & 1.15 & 229.89 & 1.15 & 344.83 & 1.15 & 459.77 & 1.15 & 574.71 & 1.15 \\
\hline $70^{\circ}\left(20^{\circ}\right)$ & & 106.38 & 1.06 & 212.77 & 1.06 & 319.15 & 1.06 & 425.53 & 1.06 & 531.91 & 1.06 \\
\hline $80^{\circ}\left(10^{\circ}\right)$ & & 102.04 & 1.02 & 204.08 & 1.02 & 306.12 & 1.02 & 408.16 & 1.02 & 510.20 & 1.02 \\
\hline $90^{\circ}\left(0^{\circ}\right)$ & & 100.00 & 1.00 & 200.00 & 1.00 & 300.00 & 1.00 & 400.00 & 1.00 & 500.00 & 1.00 \\
\hline
\end{tabular}

$\mathrm{h}$ : Thickness of the vadose zone; $\alpha_{1}$ : Inclination of the fracture and fault; $\alpha_{2}$ : Bed inclination; f.a.h.: Specific shaft length.

The number in brackets refers to the degree of the deviation from vertical.

Table 4: Potential shaft lengths of complex shafts in case of a vadose zone thickness of $100 \mathrm{~m}$ if the shaft sections along bedding plane and fracture developed in a zone with a thickness of 50-50 m.

\begin{tabular}{|c|c|c|c|c|c|c|c|c|}
\hline \multirow[t]{2}{*}{$\alpha_{1}$} & $\alpha_{2}$ & f.a.h. & $\alpha_{2}$ & f.a.h. & $\alpha_{2}$ & f.a.h. & $\alpha_{2}$ & f.a.h. \\
\hline & $10^{\circ}$ & & $20^{\circ}$ & & $30^{\circ}$ & & $40^{\circ}$ & \\
\hline $30^{\circ}$ & 394.00 & 3.94 & 247.06 & 2.47 & 200 & 2.00 & 178.12 & 1.78 \\
\hline $40^{\circ}$ & 372.12 & 3.72 & 225.18 & 2.25 & 178.12 & 1.78 & 156.24 & 1.56 \\
\hline $50^{\circ}$ & 358.94 & 3.59 & 212.00 & 2.12 & 164.94 & 1.65 & 143.06 & 1.43 \\
\hline $60^{\circ}$ & 351.47 & 3.51 & 204.00 & 2.04 & 157.47 & 1.57 & 135.59 & 1.36 \\
\hline $70^{\circ}$ & 345.55 & 3.46 & 200.25 & 2.00 & 151.55 & 1.52 & 129.67 & 1.30 \\
\hline $80^{\circ}$ & 345 & 3.45 & 198.08 & 1.98 & 151.02 & 1.51 & 129.14 & 1.29 \\
\hline $90^{\circ}$ & 344 & 3.44 & 197.06 & 1.97 & 150.00 & 1.50 & 128.12 & 1.28 \\
\hline
\end{tabular}

$\alpha_{1}$ : Inclination of fracture and fault; $\alpha_{2}$ : Bed inclination; f.a.h.: Specific shaft length.

Table 5: Potential shaft lengths of complex shafts in case of a vadose zone thickness of $500 \mathrm{~m}$ if the shaft sections along bedding plane and fracture developed in a zone with a thickness of 50-50 m.

\begin{tabular}{|c|c|c|c|c|c|c|c|c|}
\hline \multirow[t]{2}{*}{$\alpha_{1}$} & $\alpha_{2}$ & f.a.h. & $\alpha_{2}$ & f.a.h. & $\alpha_{2}$ & f.a.h. & $\alpha_{2}$ & f.a.h. \\
\hline & $10^{\circ}$ & & $20^{\circ}$ & & $30^{\circ}$ & & $40^{\circ}$ & \\
\hline $30^{\circ}$ & 1970.59 & 3.94 & 1235.29 & 2.47 & 1000.00 & 2.00 & 890.62 & 1.78 \\
\hline $40^{\circ}$ & 1861.21 & 3.72 & 1125.91 & 2.25 & 890.62 & 1.78 & 781.24 & 1.56 \\
\hline $50^{\circ}$ & 1795.27 & 3.59 & 1059.97 & 2.12 & 824.68 & 1.65 & 715.30 & 1.43 \\
\hline $60^{\circ}$ & 1757.95 & 3.51 & 1022.65 & 2.04 & 787.36 & 1.57 & 677.98 & 1.36 \\
\hline $70^{\circ}$ & 1736.55 & 3.46 & 1001.25 & 2.00 & 765.56 & 1.52 & 656.58 & 1.30 \\
\hline $80^{\circ}$ & 1725.69 & 3.45 & 990.35 & 1.98 & 755.10 & 1.51 & 645.72 & 1.29 \\
\hline $90^{\circ}$ & 1720.59 & 3.44 & 985.29 & 1.97 & 750.00 & 1.50 & 640.62 & 1.28 \\
\hline
\end{tabular}

$\alpha_{1}$ : Inclination of fracture and fault; $\alpha_{2}$ : Bed inclination; f.a.h.: Specific shaft length.

developed along bedding planes and fractures (faults) to rock beds with a vertical expansion of 50-50 $\mathrm{m}$ (with the above mentioned fracture and bedding plane inclinations) and then we summed up these values (Figure $8 b$, Tables 4 and Table 5).

For this, we determined the length of the shaft $\left(\mathrm{L}_{\mathrm{f}}\right)$, that developed along a fracture (fault) with an inclination of $\alpha_{1}$ and which belongs to the vadose zone with a thickness of $50 \mathrm{~m}$ $\left(h_{50}\right)$ and then the length of the shaft $\left(L_{b}\right)$ that was formed along a bedding plane with a dip of $\alpha_{2}$ which belongs to the vadose zone with a thickness of $50 \mathrm{~m}\left(\mathrm{~h}_{50}\right)$.

$$
\sin \alpha_{1}=\frac{L_{S 0}}{L_{f}}
$$


Citation: Veress M (2019) Shaft Lengths and Shaft Development Types in the Vadose Zone of the Bakony Region (Transdanubian Mountains, Hungary). J Soil Water Sci 3(1):54-74

Table 6: Potential shaft lengths of complex shafts in case of a vadose zone thickness of $100 \mathrm{~m}$ in case of equal and different shaft sections that developed along fractures and bedding planes, if the fracture has an inclination of $80^{\circ}$ and the dip of the bed is $10^{\circ}$.

\begin{tabular}{|l|l|l|l|l|}
\hline $\begin{array}{l}\text { Length of the shaft section that } \\
\text { developed along fracture }\end{array}$ & $\begin{array}{l}\text { Length of a shaft that developed } \\
\text { along bedding plane }\end{array}$ & $\begin{array}{l}\text { Total shaft } \\
\text { length }\end{array}$ & $\begin{array}{l}\text { Specific shaft } \\
\text { length }\end{array}$ & $\begin{array}{l}\text { The deviation of the vadose zone } \\
\text { from the given (of 100-m) width }\end{array}$ \\
\hline 5.0 & 5.0 & 180.0 & 1.73 & 4.22 \\
\hline 10.0 & 10.0 & 180.0 & 1.73 & 4.31 \\
\hline 20.0 & 10.0 & 150.0 & 1.40 & 7.65 \\
\hline 10.0 & 20.0 & 240.0 & 2.25 & 6.56 \\
\hline
\end{tabular}

$$
\begin{aligned}
& L_{f}=\frac{L_{50}}{\sin \alpha_{1}} \\
& \sin \alpha_{2}=\frac{L_{50}}{L_{b}} \mathrm{c} \\
& L_{b}=\frac{L_{50}}{\sin \alpha_{2}}
\end{aligned}
$$

In case of a complex shaft, the total length of potential shafts can be calculated as follows.

$$
L=\frac{h}{100}\left(L_{f}+L_{b}\right)
$$

Complex shaft length was calculated (in case of a vadose zone thickness of $100 \mathrm{~m}$ and of given dip angles) for a given shaft length with equal values and then for shaft lengths with different values (Figure $8 \mathrm{c}$ and Table 6). To this, vertical projection values $\left(\mathrm{L}_{\mathrm{fv}}\right.$ and $\left.\mathrm{L}_{\mathrm{bv}}\right)$ belonging to fractures $\left(\mathrm{L}_{\mathrm{f}}\right)$ and bedding planes $\left(L_{b}\right)$ were determined:

$$
\begin{aligned}
& L_{f v}=L_{f} \cdot \sin \alpha_{1} \\
& L_{b v}=L_{b} \cdot \sin \alpha_{2}
\end{aligned}
$$

The sum of $L_{f v}$ and $L_{b v}$ will be $h_{e}$. Based on this, a quotient can be formed $(A)$, that gives how many of the given shaft lengths $\left(L_{f}\right.$ and $\left.L_{b}\right)$ occupy the width of the given vadose zone. Therefore, $A$ can be formed in the following way:

$$
A=\frac{h}{h_{e}}
$$

With knowledge of $A$, the potential length of a complex shaft belonging to a vadose zone with a given width is calculated in the following way:

$$
L=\mathrm{A}\left(L_{f}+\mathrm{L}_{b}\right)
$$

The potential specific shaft length and the explored specific shaft length can be calculated for both simple and complex shafts. The former in way that we take the quotient of the potential shaft length and the vertical value belonging to it. The latter in a way that we form the quotient of the explored shaft length and the vertical value belonging to it (Table 1). As the shafts continue beyond the explored section (and this latter length is unknown) of course the actual specific shaft length cannot be given.

The data of explored caves were compared in some karst areas of the Bakony Region thus, their average vertical size, their average specific length as well as the elevation differences between the shaft floors and the karst water level with the help of the data of the shafts included in the cave cadastral database of the mountains [43]. The data of 83 explored shafts of the mountains were used for this reason. The shafts of some concealed karst areas excluded from the study were left out from data processing (for example Porvai basin) and some caves of Tési Plateau which were impossible to determine whether they could be regarded shafts or not.

\section{Results}

In case of simple shafts, potential shaft lengths increase with the growth (increase) of the vadose zone thickness and with the decrease of the inclination of the shafts (Table 3 ). In case of shafts with a small dip of $10^{\circ}$ and a vadose zone with a thickness of $100 \mathrm{~m}$, the maximum potential shaft length is $588.23 \mathrm{~m}$, while it is $2941.18 \mathrm{~m}$ in case of a thickness of $500 \mathrm{~m}$. In case of shafts with an identical spatial position, the degree of length increase is the same with the growth of the vadose zone thickness: As many times the thickness of the vadose zone increase, as many times the potential shaft length increases. Thus, for example the potential length of shafts with a spatial position (inclination) of $30^{\circ}$ grows by $200-200 \mathrm{~m}$ as the thickness of the vadose zone increases by $100-100 \mathrm{~m}$. The smaller dip the shaft has, the larger the extent of growth is during the increase of the vadose zone. Thus, in case of a shaft with vertical position, the degree of the increase of shaft length is $100-100 \mathrm{~m}$ during the growth of a vadose zone with an expansion of $100 \mathrm{~m}$. However, in case of shafts with an inclination of $10^{\circ}$, the degree of increase is $588.24 \mathrm{~m}$. In case of a small vadose zone thickness of $100 \mathrm{~m}$, the change of the shaft length is between $294.13 \mathrm{~m}$ (at an inclination change of $10^{\circ}$ and $20^{\circ}$ ) and $2.04 \mathrm{~m}$ (at a dip change of $80^{\circ}$ and $90^{\circ}$ ) with the change of the spatial position of the shafts, but the length increases to a larger and larger degree with the decrease of the inclination. In case of an increasingly larger vadose zone thickness, the increase of the shaft length is increasingly larger with the decrease of the shaft inclination. Thus, in case of a vadose zone thickness of $500 \mathrm{~m}$, if the shaft inclination decreases from $30^{\circ}$ to $20^{\circ}$, the change of the potential shaft length is $470.59 \mathrm{~m}$, while in case of a vadose zone thickness of $100 \mathrm{~m}$, if the inclination decreases from $30^{\circ}$ to $20^{\circ}$, the change of shaft length is only $94.11 \mathrm{~m}$. In case of the same vadose zone thickness, with the change of the spatial position of the shaft, the degree of length change is somewhat larger than in case of a shaft with the same spatial position, but in case of a vadose zone with changing thickness. Thus, in case of a vadose zone with the same thickness, the quotient of the 
Citation: Veress M (2019) Shaft Lengths and Shaft Development Types in the Vadose Zone of the Bakony Region (Transdanubian Mountains, Hungary). J Soil Water Sci 3(1):54-74

shaft length with the smallest inclination and of that with the largest dip is 5.88 (at a vadose zone with a thickness of $100 \mathrm{~m}$, the quotient of the lengths with a dip of $10^{\circ}$ and $90^{\circ}$ ), while in case of a shaft with the same inclination, but in case of a different vadose zone thickness $(100 \mathrm{~m}$ and $500 \mathrm{~m})$ the value of length quotients is 5.00 .

With the exception of simple shafts having a dip of $10^{\circ}$, the length of complex shafts is larger than that of simple shafts in case of a vadose zone thickness of $100 \mathrm{~m}$. In case of a simple shaft with an inclination of $20^{\circ}$, the potential shaft length is $294.11 \mathrm{~m}$, while in case of a complex shaft, if the inclination of the section with bedding plane is $10^{\circ}$ and the section along the fracture has a dip of $30^{\circ}$, the potential shaft length is $394.00 \mathrm{~m}$ (Table 3 and Table 4). However in case of a vadose zone thickness of $500 \mathrm{~m}$, at sections with an inclination of $40^{\circ}$ situated along the beds, the length of the complex shaft is only longer than the length of the simple shaft when the dip of the shaft sections of the complex shaft situated along the fracture is larger than $50^{\circ}$. (In case of a simple shaft and an inclination of $50^{\circ}$, the length is $649.35 \mathrm{~m}$, while in case of a complex shaft it is $715.30 \mathrm{~m}$.) Consequently, if the inclination of simple shafts is small, then the length and specific length of complex shafts is exceeded by the length and specific length of simple shafts. In case of complex shafts, at sections along fractures with the same inclination, as the steepness of the section along the bedding plane increases, their total length decreases. Thus, in case of a vadose zone thickness of $100 \mathrm{~m}$, as the steepness of the shaft section that developed along a bedding plane increases from $10^{\circ}$ to $40^{\circ}$ if the sections along fractures have a dip of $30^{\circ}$, the potential total length decreases from $394.00 \mathrm{~m}$ to $178.12 \mathrm{~m}$ (Table 4). The total shaft length decreases similarly, if the steepness of the shaft sections that developed along fractures increases. However, in this case the degree of the decrease is smaller. When the sections along fractures are increasingly steeper (from $30^{\circ}$ to $90^{\circ}$ ) and the steepness of the sections along the bedding plane is $10^{\circ}$, then the decrease of potential shaft length is only $50 \mathrm{~m}$ in case of a vadose zone with a $100 \mathrm{~m}$ thickness.

In case of shaft sections with the same position, also in case of complex shafts, the growth of the vadose zone thickness determines the increase of the total length of shafts. As many times the vadose zone thickness increases, as many times the total length grows. Thus, in case of shaft sections along bedding planes with a dip of $10^{\circ}$ and those along fractures with a dip of $30^{\circ}$, the total length is $394.00 \mathrm{~m}$, while in case of $500-\mathrm{m}$ thick vadose zone, this value is $1970.59 \mathrm{~m}$ (Table 4 and Table 5).

The specific potential shaft length values change as the steepness of the shaft sections along fractures and bedding planes changes, but their values do not depend on the change of the vadose zone thickness (Table 3, Table 4 and Table 5).

In case of given dip angles, when some shaft parts are of the same length, if the degree of stepped nature increases (in this case we change the length of shaft parts, but to a similar extent) the potential length of complex shafts does not change (Table 4). However, if the lengths of different shaft sections changes as compared to each other, the potential length of shafts and also their specific potential shaft length changes
(Table 4). The total shaft length increases if the length of the shaft part with a smaller inclination increases as compared to the shaft part with a larger dip.

The $h_{2}$ (local vadose zone thicknesses) values for the various karst areas of the mountains were given (Table 7). It can be seen that this value is larger than $400 \mathrm{~m}$ in case of the Eleven-Förtés doline group. Its value is probably smaller here too since the thickness of limestone was calculated as 339 $m$ taken the bed inclination of the nearby dolomite outcrop into consideration. The cavity formation of the dolomite constituting the bedrock of limestone is of lower degree and thus, the chance of shaft development is also smaller in the rock. Therefore when determining the $h_{2}$ value, only the thickness of the limestone was considered.

Therefore, the thickness of the local vadose zone below the various karst areas of the Bakony Region is $200 \mathrm{~m}-400 \mathrm{~m}$. The values on the Middle Cretaceous limestone blocks (for example Mester-Hajag, Égett Hill) and on Kab Hill are smaller than this value.

Thus, considering the elevation of the springs at the margin of blocks (the spring with the most elevated position has an altitude of $482 \mathrm{~m}$ ), the elevation of karst water level may reach $482 \mathrm{~m}$ on Mester-Hajag (the elevation of its surface is $450-503 \mathrm{~m}$ ), while this elevation is about $350 \mathrm{~m}$ according to Kálmán, Pethő [44]. (Therefore, the vadose zone thickness is about $21-68 \mathrm{~m}$ in the former case, and it is $50-100 \mathrm{~m}$ in the latter.) In both cases, karst water storeys developed because of local impermeable intercalations.

Presuming simple shafts, in case of a preforming structure with an inclination of $20^{\circ}$ and at a vadose zone of $200 \mathrm{~m}$, the value of potential shaft length is $588.23 \mathrm{~m}$, and in case of a vadose zone of $400 \mathrm{~m}$ this value is $1176.47 \mathrm{~m}$. On Kab Hill, in case of a preforming structure with the same position, but calculating with a vadose zone of $100 \mathrm{~m}$ this value is 294.11 $\mathrm{m}$. In case of a preforming structure with a dip of $70^{\circ}$ at vadose zones of $200 \mathrm{~m}-400 \mathrm{~m}$, the potential shaft lengths are between $212.77 \mathrm{~m}$ and $425.53 \mathrm{~m}$ (on Kab Hill, calculating with a vadose zone of $100 \mathrm{~m}$ this length is $106.38 \mathrm{~m}$ ). In case of the development of complex shafts, at a vadose zone with a thickness of $200 \mathrm{~m}$, in case of shaft parts with equal lengths that developed along fractures of $70^{\circ}$ and bedding planes of $20^{\circ}$ the potential shaft length is $400.5 \mathrm{~m}$, and it is $801.00 \mathrm{~m}$ in case of a vadose zone of $400 \mathrm{~m}$. In case of a vadose zone of $100 \mathrm{~m}$ (Kab Hill), at shaft parts with this same position, the potential shaft length is $200.25 \mathrm{~m}$.

Potential shaft lengths are also limited by the small lateral expansion of the blocks of the mountains. The majority of the blocks of the mountains has an expansion of some $100 \mathrm{~m}$ and 1-2 km. For example for the development of a simple shaft with a $1000 \mathrm{~m}$ length and an inclination of $30^{\circ}$ in any block, it is a precondition that the block must have an expansion of at least $866 \mathrm{~m}$ in the direction of the shaft. Among the blocks there are only two with a larger expansion: Tési Plateau (in NS direction $8 \mathrm{~km}$, in EW direction $16 \mathrm{~km}$ ) and Köris Hill (its NS and EW expansion is about 6-6 km). The area of Kab Hill is of relatively significant expansion, but the majority of it is covered by basalt. 
Citation: Veress M (2019) Shaft Lengths and Shaft Development Types in the Vadose Zone of the Bakony Region (Transdanubian Mountains, Hungary). J Soil Water Sci 3(1):54-74

Table 7: The shaft groups of the mountains according to karst areas and some characteristics of their development environment.

\begin{tabular}{|c|c|c|c|c|c|c|c|c|}
\hline Karst area & $\begin{array}{l}\text { Present karst } \\
\text { type }\end{array}$ & $\begin{array}{l}\text { Surface } \\
\text { elevation } \\
\text { (m) }\end{array}$ & $\begin{array}{l}\text { Elevation of } \\
\text { karst water } \\
\text { level(m) }\end{array}$ & $\begin{array}{l}\text { Thickness of } \\
\text { local vadose } \\
\text { zone }(\mathrm{m})\end{array}$ & $\begin{array}{l}\text { Number } \\
\text { of karst } \\
\text { depressions }\end{array}$ & $\begin{array}{l}\text { Average } \\
\text { depth of } \\
\text { explored } \\
\text { shafts }^{1}\end{array}$ & $\begin{array}{l}\text { Average } \\
\text { specific shaft } \\
\text { length of } \\
\text { explored } \\
\text { caves }\end{array}$ & Shaft genetics \\
\hline Kab Hill & $\begin{array}{l}\text { Concealed } \\
\text { and mixed } \\
\text { allogenic- } \\
\text { autogenic karst }\end{array}$ & $400-450$ & 350 & $50-100$ & $40^{2}$ & $23.53(11)$ & 3.89 & \multirow[t]{2}{*}{$\begin{array}{l}\text { Karst water and } \\
\text { surface flood shaft } \\
\text { development }\end{array}$} \\
\hline Tési Plateau & $\begin{array}{l}\text { Concealed } \\
\text { karst }\end{array}$ & $420-480$ & 200 & $220-280$ & 137 & $30.13(46)$ & 2.73 & \\
\hline Hárskút basin & $\begin{array}{l}\text { Concealed } \\
\text { karst }\end{array}$ & $460-500$ & 250 & $210-250$ & 60 & $12.07(7)$ & 2.04 & $\begin{array}{l}\text { Weak surface flood } \\
\text { and karst water } \\
\text { shaft development }\end{array}$ \\
\hline $\begin{array}{l}\text { Eleven Förtés } \\
\text { doline group }\end{array}$ & $\begin{array}{l}\text { Concealed } \\
\text { karst }\end{array}$ & 675 & 230 & 445 & 9 & $10.25(4)$ & 1.00 & \multirow[t]{3}{*}{$\begin{array}{l}\text { Surface flood shaft } \\
\text { development }\end{array}$} \\
\hline $\begin{array}{l}\text { Environs of } \\
\text { Márvány Valley }\end{array}$ & $\begin{array}{l}\text { Concealed } \\
\text { karst }\end{array}$ & $410-620$ & 180 & $230-440$ & 120 & 7.17 (3) & 1.20 & \\
\hline $\begin{array}{l}\text { Area between } \\
\text { Som Hill and } \\
\text { Száraz-Gerence } \\
\text { Valley }\end{array}$ & $\begin{array}{l}\text { Concealed } \\
\text { karst }\end{array}$ & $500-600$ & 250 & $250-350$ & 76 & $14.00(5)$ & 1.43 & \\
\hline $\begin{array}{l}\text { Keszthely } \\
\text { Mountains }\end{array}$ & $\begin{array}{l}\text { Bare or } \\
\text { concealed karst }\end{array}$ & $400-420$ & 115 & $285-305$ & $20^{2}$ & $62.7(7)$ & 42.64 & $\begin{array}{l}\text { At a small amount } \\
\text { of surface water } \\
\text { supply at tectonic } \\
\text { shafts }\end{array}$ \\
\hline
\end{tabular}

${ }^{1}$ In brackets the number of the shafts taken into consideration; ${ }^{2}$ Estimated data.

If we look at the explored shaft lengths of the various karst areas of the Bakony Region, they can be put into the following groups according to their average depth, the position of shaft floors as compared to the karst water level, their number, and their average explored specific length (Table 7 and Table 8).

- Where the average depth and the average specific length of the shafts is large, and the frequency of shafts is also relatively large in the bearing area. In these areas, the elevation difference of the shaft floors (or of some shafts) and of the karst water level and also the vadose zone thickness is small. Kab Hill and Tési Plateau belong to this group. The average, explored specific shaft length of these two karst areas is 3.31. There is a relation between the vertical size and specific length. Thus, if we look at the shafts of Tési Plateau deeper than $50 \mathrm{~m}$, their average specific length is 5.32 , while in case of all investigated shafts of the plateau, this value is 2.73 .

- Where the average depth and average specific length of the shafts is small, and the shaft frequency of the bearing area is also small. In these areas, the thickness of the vadose zone and the elevation difference between the shaft floors and the karst water level is large. Kőris Hill (the environs of Márvány Valley, the Eleven Förtés doline group) and the surroundings of Köris Hill (the area between Som Hill and Száraz-Gerence) belong to this group. In these karst areas, the average specific length of the shafts is 1.21 . This group also may involve several concealed karst areas, in the vadose zone of which no shafts have been explored at all (for example Égett Hill with
Middle Cretaceous limestone) and also those where shafts do occur but only with a small depth (Középső-Hajag), or which are not active anymore and are only some metres deep (the Middle Cretaceous block of Mester-Hajag).

The shafts of Hárskút basin make a transition between the two groups. Here, the average specific length of the shafts is relatively large, their depth is small, but the thickness of the vadose zone is small too. Extreme specific lengths and vertical values can be found in Keszthely Mountains. However, the thickness of the vadose zone is large here.

\section{Discussion}

The potential shaft length is large if the vadose zone is thick and not interrupted by an impermeable bed and if there is a great chance of the development of complex shafts. The latter is favoured by the large fracture density and the wellbedded nature of the rock. The chance of the development of long or increasingly longer complex shafts increases if the dip of the fracture (fault) and the bed inclination is small. Another condition of large shaft length is the large lateral expansion of the bearing blocks. The vertical size is large if the shafts frequently receive not a too large amount of water for a longer period (the development of water film on shaft walls) and the shaft development has been in progress for a long time. Small, but long-lasting water supply is favoured by the partial infilling of the doline since in this case, the drainage is restrained and also by the intermittent springs of the superficial deposit of the depression [29] and the infilled 
Citation: Veress M (2019) Shaft Lengths and Shaft Development Types in the Vadose Zone of the Bakony Region (Transdanubian Mountains, Hungary). J Soil Water Sci 3(1):54-74

Table 8: Elevation differences between shaft floors and karst water level in two karst areas of the mountains.

\begin{tabular}{|c|c|c|c|c|c|}
\hline Name of the shaft & Shaft depth (m) & $\begin{array}{l}\text { Elevation difference } \\
\text { between shaft floor } \\
\text { and karst water } \\
\text { level }(\mathrm{m})\end{array}$ & $\begin{array}{l}\text { Explored } \\
\text { specific } \\
\text { length }\end{array}$ & Shaft type & Position $(\alpha)$ \\
\hline $\begin{array}{l}\text { The shaft of the depression marked } \\
1 \text { of eleven-Förtés doline group }{ }^{1}\end{array}$ & $5.0(675.0)$ & 440.0 & 1.0 & Simple & $90^{\circ}$ \\
\hline $\begin{array}{l}\text { The shaft of the depression marked } \\
2 \text { of Eleven-Förtés doline group }{ }^{1}\end{array}$ & $13.0(675.0)$ & 432.0 & 1.0 & Simple & $90^{\circ}$ \\
\hline $\begin{array}{l}\text { The shaft of the depression marked } \\
7 \text { of Eleven-Förtés doline group }{ }^{1}\end{array}$ & $19.0(675.0)$ & 426.0 & 1.0 & Simple & $90^{\circ}$ \\
\hline The shaft of Dózeros depression ${ }^{1}$ & $4.0(675.0)$ & 441.0 & 1.0 & Simple & $90^{\circ}$ \\
\hline Average & $10.25(675.0)$ & 434.75 & 1.0 & -- & --- \\
\hline Alba Regia cave ${ }^{2}$ & $200.2(453.0)$ & 52.8 & 17.98 & Storeyed & between $20^{\circ}-30^{\circ} 4$ \\
\hline Csengő shaft ${ }^{2}$ & $133.9(480.0)$ & 146.1 & 1.72 & Complex & $90^{\circ 3}$ \\
\hline Csipkés shaft ${ }^{2}$ & $72.5(413.0)$ & 140.5 & 2.48 & Complex & $90^{\circ}$ \\
\hline Háromkürtő shaft ${ }^{2}$ & $105.0(442.0)$ & 137.0 & 3.43 & Shaft system & $\begin{array}{l}90^{\circ 3} \text { (both the main shaft } \\
\text { and the tributary shaft) }\end{array}$ \\
\hline Jubileum shaft ${ }^{2}$ & $121.0(410.0)$ & 89.0 & 1.84 & Complex & $90^{\circ}$ \\
\hline Shaft of Tábla Valley² & $78.0(462.0)$ & 184.0 & 4.49 & Bifurcating & Between $30^{\circ}-50^{\circ}, 70^{\circ}$ \\
\hline Average & $118.43(433.3)$ & 124.9 & 5.32 & -- & --- \\
\hline
\end{tabular}

Notice:

- The shafts deeper than $50 \mathrm{~m}$ on Tési Plateau were taken into consideration

- The elevation of karst water level can be seen in Table VII

- The value in brackets refers to the altitude of the shaft entrance

- ${ }^{1}$ The shaft of the Eleven-Förtés doline group

- ${ }^{2}$ The shaft of Tési Plateau,

- ${ }^{3}$ Shaft section along fracture,

- "Shaft section along bedding plane,

- $\alpha$ : Shaft angle to the horizontal

- Data on the size of the shafts were taken from

http://www.termeszetvedelem.hu/index.php?pg=caves\&mode=search\&name=\&katszam=2892\&city=\&hrsz=\&length_ comp=al\&length $=0 \&$ vertkit_comp $=a \mid \& v e r t k i t=0 \&$ depth_comp $=a l \& d e p t h=0 \&$ height

comp=al\&height=0\&protection=0\&visiting $=0$ \&orderby=name\&direction=asc\&headers $=50$ [43].

nature of the upper part of the shaft with washed-in cover deposit or debris.

The explored shaft sections may even reach or exceed the potential shaft length. This may be expected in case of storeyed shafts, bifurcating shafts and shaft systems. The Alba Regia cave is a good example for this, whose length is $3600 \mathrm{~m}$ (Figure 4). The potential shaft length is $400 \mathrm{~m}$ at the cave, calculating with a vadose zone thickness of $200 \mathrm{~m}$ and with a bed inclination of $30^{\circ}$ [41] (this corresponds to explored length since the expansion of the Main branch is $406.25 \mathrm{~m}$ ).

The development of an explored (or actual) shaft length exceeding the potential shaft length can be expected if the shaft is formed in a paragenetic way. A paragenetic shaft development takes place since the shafts are situated above the karst water level if the shaft is regularly filled in (flooded) with water [29]. The paragenetic effect is more effective if the flooding of the shafts with water is of increasingly longer duration and happens more frequently.
Paragenesis is an upward cavity formation $[45,46]$ which has been studied by several researchers [4,47-53]. During the process, dissolution takes place above or in the already existing cavity or since the accumulating sediment presses the water upwards $[50,54]$. Paragenesis may take place in the phreatic zone $[4,46,54,55]$ in the epiphreatic zone $[54,55]$ and in the vadose zone [50]. In the latter case also in a way that the infilled passage gets from a phreatic environment into a vadose environment as a result of the subsidence of the karst water level [56]. Among features developing during paragenesis are mentioned phreatic canyons [50,54] ceiling channels [46,54,57] anastomoses [50,58] half-tubes [50], ceiling pendants $[46,55,57]$ and notches [50].

The intermittent lakes of depressions refer to the infilled state of shafts with water $[23,59]$ when the lakes develop in depressions in which the entrance of the shaft is not covered with sediment. However, this water infilled characteristic is also proved by the fact that the shaft walls are covered with veneers of sediment and plant waste [60] since the suspended 
Citation: Veress M (2019) Shaft Lengths and Shaft Development Types in the Vadose Zone of the Bakony Region (Transdanubian Mountains, Hungary). J Soil Water Sci 3(1):54-74

sediment and plant waste adheres to various surfaces (and thus, to shaft walls) from the not moving or very slowly moving water. The formation of veneer (of colloidal material and plant waste) has been observed from the slowly moving water of the intermittent lakes of the karstic depressions of the mountains $[29,59]$.

The water filled state of the shaft with can be attributed to the characteristics of the shaft (the shaft is narrow, its inclination is low, its lower parts are partially filled) as well as to surface and subsurface causes. A triggering cause at the surface is an intensive rainfall event, the suitable morphology of the surface (the depression is of valley floor position or it is connected by a water collecting and water draining feature for example a valley or it has a relatively large catchment area).

A subsurface cause is the rising karst water level which can approach or reach the shaft floor or it can even exceed the elevation of the floor partially filling the shaft. Particularly in the latter case, the water flowing in from the surface is not able or is only able to be drained to a small degree (laterally). Thus, the karst water may promote the shaft parts to become flooded by surface waters. The significant rise of the karst water level, exceeding $100 \mathrm{~m}$ has already been mentioned. The subsidence of karst water level is extremely slow at the measurement site (near Hárskút). While its rise was $1.87 \mathrm{~m} /$ day at the above mentioned site, its subsidence was 0.28 $\mathrm{m} /$ day [38]. The slow sinking in the shafts may permanently maintain the filled nature with karst water. The permanence of water filling is also proved by the fact that the fine (colloidal) veneers of the shaft walls only develop in case of long-lasting water filling. The flooding of the shaft with karst water and its duration depend on several factors. The chance of flooding is great if the altitude difference between the karst water level and the shaft entrance is small (thus, the thickness of the vadose zone is small), the degree of the rise of the karst water level is large (this is controlled by the degree to which the rock has cavities), the shaft floors extend deep into the vadose zone. (This latter happens if the shaft development has been taking place for a long time and if it is intensive).

A lower extent of having cavities favours the karst water level rise of greater degree. In the mountains, there is a greater chance of this where the limestone beds bearing the shaft has a small thickness and thus, the main dolomite is of high position below it, its surface is above the standstill level of the main karst water.

The water-filled state of the shafts may mainly contribute to the development of shaft systems. Blind shafts branching out from the shafts are common in the shafts of the mountains [29]. They are of various position and length, they are straight or arcuate. They do not reach the surface, but they terminate in the host rock (Figure 5 and Figure 6). The upward development of the blind shafts thus, their paragenetic genetics is proved by the fact that they are vertical, upward narrowing features terminating closed at their upper section and are connected to the bearing shaft.

The development of shaft systems is possible if the shaft has paragenetic blind shafts which may develop into tributary shafts by growing upwards and reaching the surface. The level of flooding by water and thus, the level of paragenetic cavity formation, if it is partially (or completely) caused by surface water inflows, may reach the elevation of the karstic depression from which water supply happens. Thus, paragenetic blind shafts may approach or reach the surface if the elevation of the surface is lower above the blind shafts than at the water inlet depression [29]. The upward growth of paragenetic blind shafts is also contributed by the sediment accumulating in the shafts [29]. A shaft system is formed from the simple or complex shaft. It can often be experienced that above the paragenetic blind shaft, there are no subsidence dolines at the surface (above the Bertalan branch of the cave of Figure 4 and Figure $5 \mathrm{~A}$ ). In this case during the development of the upward developing blind shaft turning into a tributary shaft may probably contribute to the development of a newer doline. Consequently, the subsidence doline that develops above the tributary shaft (tributary doline), since a further water inlet takes place here, further increases the degree to and the duration of which the shaft system is filled with water.

Below, we analyse why the chances of the shafts to become filled with water is different in the various karst areas of the mountains. If no water drain feature (valley, creek, gully) is connected to the subsidence doline it refers to the chance of a smaller surface water inflow. The amount of water inflow is also referred to by the size of the catchment area of the subsidence dolines. Although the catchment area of a subsidence doline cannot be determined (since its borders cannot be pointed out), it can be made proportionate with the doline density of a given area. The higher the doline density at a site the smaller doline catchment area can be expected.

None of the subsidence dolines in the environs of MesterHajag and Márvány Valley are connected by a water drainage feature. Whereas 5 out of 60 subsidence dolines of Hárskút basin are connected by such features and 4 of them have a valley floor position. On Kab Hill all depressions having shafts are connected by water drain features. In the eastern part of Tési Plateau, in a well-confinable area there are 20 depressions. Among them 16 depressions are situated on the valley floor (erosional channels are connected to several of them), one of them is connected by a gully and only 4 depressions are on a flat surface which are not connected by water drain features either. Thus according to surface morphology, in the area of Kab Hill, Tési Plateau and Hárskút basin, the chance of water inflow is greater into the karstic depression than in the area surrounding Mester-Hajag or Márvány Valley.

In a certain area of Mester-Hajag with an expansion of $0.076 \mathrm{~km}^{2}$, the density of dolines is 1.12 doline $/ 100 \mathrm{~m}^{2}$, in a certain area surrounding Márvány valley with an expansion of $1.28 \mathrm{~km}^{2}$ the doline density is 0.5 doline $/ 100 \mathrm{~m}^{2}$, while in a certain area of Hárskút basin, having an expansion of 3.00 $\mathrm{km}^{2}$ this value is 0.2 doline $/ 100 \mathrm{~m}^{2}$. Considering the doline densities in the three areas, in the area of Hárskút basin the chance of water inflow into the karstic depressions is larger too than in case of the other two areas. 
Citation: Veress M (2019) Shaft Lengths and Shaft Development Types in the Vadose Zone of the Bakony Region (Transdanubian Mountains, Hungary). J Soil Water Sci 3(1):54-74

The chance of flooding with karst water also depends on the thickness of the vadose zone (in addition to other, already mentioned things). In case of a small vadose zone thickness and shafts with the same depths, when the karst water level rises, the karst water can get to (or reach) the shaft floors with a larger chance and more often than in case of a vadose zone with a larger thickness. Therefore, in the former case the chance of flooding with karst water is greater. The various duration of floodings may result in various actual (and thus, explored) specific shaft length. Therefore, from the shafts of the Tési Plateau (the thickness of the vadose zone is smaller here) those were selected, the depths of which are similar to the shafts of the Eleven-Förtés doline group (the thickness of the vadose zone is larger here). However, shafts with completely identical depths did not occur. These were the following: The 18-metre deep Hétházi shaft (19 m), the shaft of the depression marked I-14 with a depth of 12.5 metres $(13 \mathrm{~m})$, the shaft of the depression marked I-27 with a depth of 6 metres $(4 \mathrm{~m})$ and the $7 \mathrm{~m}$ deep Kánkúti shaft $(5 \mathrm{~m})$. (The numbers in brackets refer to the depth of the shafts of the Eleven-Förtés doline group.) In case of the above mentioned shafts of the Tési Plateau, the average of the explored specific shaft lengths is 2.39 , while in case of the Eleven-Förtés doline group this value is 1.0. The greater specific shaft length of the Tési Plateau as compared to the Eleven-Förtés doline group (in spite of the similar depth of the shafts too) can be explained by more frequently occurring karst water floodings. Although the shafts of the Eleven-Förtés doline group are of vertical position, only one out of the 4 shafts of the Tési Plateau has a vertical position which in itself results in small specific shaft length. In case of the Eleven-Förtés doline group, the small specific length cannot be explained by the lack of surface flooding since the shafts may get a significant surface water inflow here. Among the depressions of the shafts, 2 of them are situated in a creek with a length of about 150 metres, while 1 of them is situated at its end [32].

On Middle Cretaceous blocks (Mester-Hajag), there are extremely small vadose zone thicknesses thus, the chance of karst water flooding is greater. Relatively small vadose zone thicknesses occur on Kab Hill, on Tési Plateau and in Hárskút basin. There are large vadose zone thicknesses (their thickness alternates between wide limits respectively) thus, the chance of flooding with karst water is smaller in the karstic area between Som Hill and Száraz-Gerence, and in the area surrounding Márvány Valley, at the Eleven-Förtés doline group and in the Keszthely Mountains.

The chance of flooding is also large at sites where the depth of shafts is large. The shafts of Tési Plateau, Kab Hill and Keszthely mountains are characterised by a large average shaft depth. (However, in the latter area the thickness of the vadose zone is relatively large and this does not favour flooding with karst water.) According to this, the explored specific length depends on the elevation difference between the shaft floor and the karst water level (Table 8). Thus, in case of the shafts of the Tési Plateau being deeper than 50 metre, the explored average specific shaft length is larger (5.32) than in case of the shafts of the Eleven-Förtés doline group (1.0). In the area of the former group, the average elevation difference between the shaft floors and the karst water level is $124.9 \mathrm{~m}$, while in case of the latter area, this value is $434.75 \mathrm{~m}$ (Table 8). In case of the shafts of Tési Plateau, the specific shaft length is also larger if we compare the shafts with similar position: Regarding the shafts that developed along vertical fractures, the average specific length of the 4 shafts of Tési Plateauis 2.37 thus, this is larger than the average specific length of the shafts of the Eleven-Förtés doline group (1.0). In addition to this, in case of the shafts of Tési Plateau being deeper than 50 $m$ it can be observed that a larger specific length belongs to a smaller elevation difference (Alba Regia cave). However, this relation is not valid in all cases. A larger specific length occurs in case of a shaft with a relatively large elevation difference, but which is bifurcating (the cave of Tábla Valley). While a small specific length may also occur in case of a shaft with a small elevation difference which can even be complex if the sections of the shaft which developed along fractures are of vertical position and the sections which were formed along bedding planes are short (Jubileumi shaft, Table 8).

Taking the above mentioned things into consideration, the shaft development types of the mountains are the following (Figure 10):

- Surface flood shaft development type: The deepening of the shafts is of low intensity and/or the shaft development is of young age therefore, the depth of the shafts is small. Particularly, if the vadose zone thickness is relatively large and the degree of the fluctuation of the karst water level is low, the shafts are not flooded by karst water at all or they are flooded rarely, but only to a small extent in this case too. Therefore, the water infilled state of the shafts takes place less (it is rare and of short duration). The shafts do not develop into shaft systems, to bifurcating or storeyed shafts. Such a shaft development is specific of the shafts of the concealed karst in the the environs of Márvány Valley, that of the Eleven Förtés doline group and of the area between Som Hill and Száraz-Gerence. The explored or actual shaft lengths are determined by the potential shaft lengths and they are smaller than them. The development of simple shafts and complex shafts is not favoured by a smaller amount of surface water supply either. However, it is also not favoured by the very small (some $10 \mathrm{~m}$ ) thickness of the vadose zone either. Shafts with a small depth and of some metres can be formed on Middle Cretaceous limestone blocks (or there are no shafts at all). The reason for this is that the subsidence dolines do not receive enough water (their catchment area is very small, there are no creeks connecting to them), but also because they lose their catchment area rapidly because of the denudation of the cover (since the block is of an elevated position, of small area and it is surrounded by valleys). Shaft development is probably also hindered by the fact that the water of karst water storeys approaches the surface in rainy weather, which impedes surface water inlet into the karst. The rise of karst water level with such an extent is referred to by the fact that a horizontal (thus, phreatic) passage is situated near the surface of an exhumed limestone cone of Mester-Hajag.

- Karst water and surface flood shaft development type: Shaft development is intensive or has been in process for a 


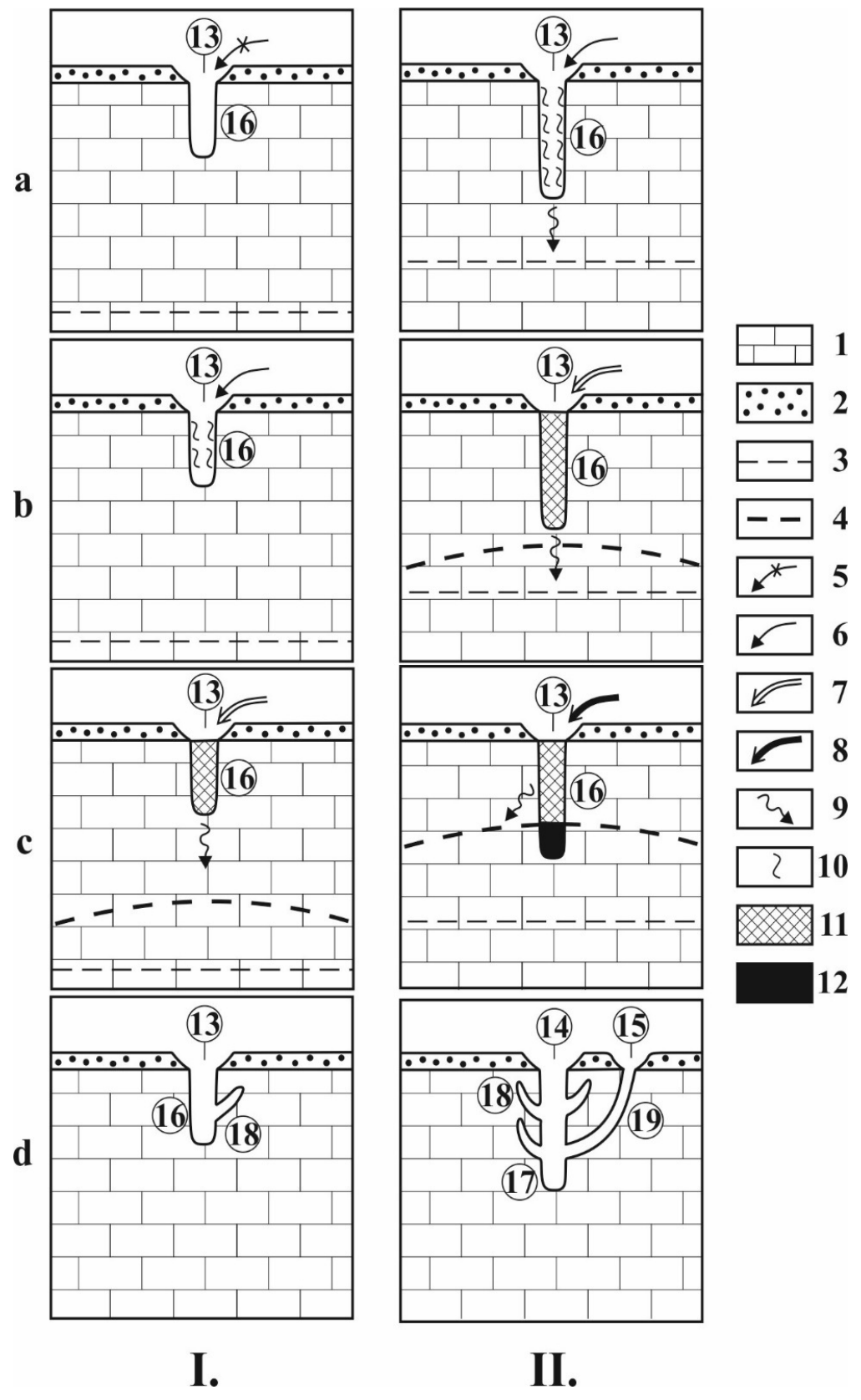

Figure 10: Factors influencing shaft flood and the effect of floods on shaft development; 1) Limestone; 2) Cover; 3) Low (standstill) karst water level; 4) High karst water level; 5) No water input; 6) Water input of low yield; 7) Water input of medium yield; 8) Water input of high yield; 9) Seepage from the shaft; 10) Water film on the shaft wall; 11) Water fill in the shaft, originating from surface water; 12) Water fill originating from karst water; 13) Subsidence doline; 14) Subsidence main doline; 15) Subsidence tributary doline; 16) Shaft; 17) Main shaft; 18) Paragenetic blind shaft; 19) Tributary shaft; I) The morphology of the surface does not favour significant water input into the shaft, the elevation difference of the shaft floor and the karst water level is great II) The morphology of the surface favours significant water input, the elevation difference of the shaft floor and the karst water level is small; a) There is little precipitation and no water inflow (la.) or it is of low yield (Ila.); b) There is more precipitation, water inflow is little (Ib.), or medium (IIb); c) There is a lot of precipitation for a long period, water inflow is medium (IC), or large (IIc); d) Shaft patterns.

longer time, the simple shafts and complex shafts are deeper. The vadose zone is a relatively smaller thickness and/or the fluctuation of karst water level is of greater degree. As a result of the above mentioned things, the shafts are flooded by karst water with a greater chance, more frequently and more permanently in addition to this, they receive more surface water. The duration of flooding and thus, the efficiency of shaft development increases when the water fill originating from the surface is coupled with flooding with karst water.
As for simple shafts and complex shafts, there is a greater chance of developing into shaft systems, storeyed shafts and bifurcating shafts. The explored or actual shaft lengths are less determined by potential shaft lengths. Such a shaft development is characteristic of the shafts of Tési Plateau and $\mathrm{Kab}$ Hill or some of them. There are favourable conditions for the development of long shafts and varied shaft patterns mainly on Tési Plateau. Among favourable conditions we can mention the relatively large lateral expansion of the plateau, 
Citation: Veress M (2019) Shaft Lengths and Shaft Development Types in the Vadose Zone of the Bakony Region (Transdanubian Mountains, Hungary). J Soil Water Sci 3(1):54-74

its arheism and its relatively long duration of karstification as compared to other parts of the mountains. The occurrence of gravel in some depressions and in their shafts refers to the fact that karstification already started on the plateau parallel with that time existing, but for today completely denuded gravel cover [23]. According to our observations, the intermittent lakes that are often formed in the depressions refer to intensive and abundant surface water supply. This is favoured by morphological characteristics since the depressions are situated either on valley floors or they have well-developed creeks $[23,27]$. On Kab Hill, such a shaft development was favoured by the small thickness of the vadose zone and the favourable morphological characteristics since the waters of the basalt cover get into the karst marginal ponors through blind valleys $[27,28]$. However, at some occurrence sites of this type (Hárskút basin) if shaft deepening is not intensive (or it is of short duration), only simple shafts and complex shafts develop because of small shaft depths even in case of a vadose zone with a relatively small thickness. (In the area of Hárskút basin, a shaft development of short duration is referred to by the fact that extensive patches of former gravel cover survived here. Thus, the development of subsidence dolines and consequently, that of shafts is of younger age than for example on Tési Plateau since they were formed on gravel-free surfaces.)

- Tectonic shaft development type: Shaft deepening only partially depends on surface water inflow, the shafts are partly, or completely of tectonic origin (some of their parts are situated below the karst water level). Since the shafts received a small amount of surface water, even their features referring to tectonic origin may survive. The tectonic origin and the phreatic passages favour the existence of large specific shaft lengths. However, the vadose zone is thick (the karst water level is situated at great depth) therefore, deep shafts can develop. As a result of this, the explored shaft lengths are large, they exceed potential shaft lengths. Keszthely Mountains are characterised by such shafts.

The specific lengths of the shafts of the Bakony Region can be compared with the specific lengths of the shafts of other karst areas thus, with the specific lengths of the shafts of glaciokarst. The specific length of Njegusi cave situated on a glaciokarst can be mentioned as an example, its value is 16.32 . The large specific length can be attributed to the fact that in addition to vadose passages, phreatic passages developed in the cave which are of horizontal or almost horizontal position [61]. The polje bearing the cave is a piedmont type polje which was partly covered by a glacier. On glaciokarsts, the karst water is impounded as a result of the fact that the karst springs become covered with ice [62]. As a result of long-lasting impoundment, phreatic passage development may take place in the vadose zone [63]. Phreatic passages of horizontal position favour the development of shaft systems of large specific shaft length.

\section{Conclusions}

The potential length of the shafts depends on the thickness of the vadose zone, on the spatial position of the developing shafts and shaft sections and on the length of forming shaft parts as compared to each other, but it does not depend on the degree of stepped character in case of complex shafts. In case of the given thickness of the vadose zone, the frequency and spatial position of the preforming geological structure affects the potential length.

The explored shaft length may reach or even exceed the potential length in case of shaft systems, bifurcating shafts and storeyed shafts. Thus, the explored shaft length depends on the shaft pattern. In addition to the above mentioned things, the actual shaft length (and thus, the explored length too) is affected by the degree of the fluctuation of the karst water level (which depends on the extent to which the rock contains cavities), on the elevation difference between the shaft floor and the karst water level and on the degree and duration of surface water supply. Since shaft length is determined by the conditions of water fill of the shaft (its degree and duration), with its knowledge at a certain shaft part an estimation can be made on the length of the shafts. (The degree of shaft flooding can be referred by the sediment veneers of the shaft walls).

In the Bakony Region, the frequency, the average depth and explored average specific length of the explored shafts of the karst areas is different. There are karst areas which have a large shaft frequency, and which bear shafts with a large average depth and large average specific length and have a relatively small vadose zone and others where the average shaft depth and the average specific length is small and the vadose zone thickness is relatively large. Floodings play a more significant role in the development of the shafts (or at some of them) of the former group than in the formation of the latter. The frequency and duration of floodings is larger at sites (Kab Hill, Tési Plateau), where surface water supplies are of greater importance, the elevation difference of the shaft floors and the karst water level is relatively small, and the fluctuations of the karst water level are significant. Consequently, shaft development is influenced by many factors. Therefore the development of shafts is individual and the diversity of the size, pattern and specific length of shafts is great even within the same karst area.

The shafts of the karst areas of the Bakony Region belong to various development types (surface flood shaft development type, karst water and surface flood development type and tectonic development type). The genetic type of the shafts of a karst area depends on the characteristics of the bearing block. Thus, on the elevation of the karst water level in the block and on the morphology of the block surface.

Although the shaft depths and shaft lengths of the Bakony Region are significant as compared to the karstification of its surface, potential shaft lengths and explored shaft lengths are not of great importance as compared to mainly high mountain karst areas (the Alps, the Dinarides, the Pyrenees, the Caucasus etc.). The relatively small thickness of the vadose zone and the heavily dissected tectonic character of the mountains (the size of the blocks is small) have a role in this. However, in high mountains, where the vadose zone thickness is large, the potential shaft lengths are significantly larger. Thus, in case of a vadose zone of $2000 \mathrm{~m}$, and a 
Citation: Veress M (2019) Shaft Lengths and Shaft Development Types in the Vadose Zone of the Bakony Region (Transdanubian Mountains, Hungary). J Soil Water Sci 3(1):54-74

preforming geological structure with an inclination of $10^{\circ}$, the potential shaft length is $11764 \mathrm{~m}$, while at a dip of $40^{\circ}$, this value is $3125 \mathrm{~m}$. Since as a result of the great amount of meltwaters and the long duration of their flow into the karst, the conditions of shaft development are favourable, on high mountain karst, there is a great chance of the fact that large potential shaft lengths are associated with large actual shaft lengths.

On karsts where the karst water appears long-lastingly in the vadose zone, larger specific shaft lengths can be expected.

\section{References}

1. Jakucs L (1973) Általános természeti földrajzi gyakorlatok (General physical geographical exercises). Tankönyvkiadó, Budapest, Hungarian, 243.

2. Tobin B, Doctor DH (2009) Estimating karst conduit length using conductivity and discharge measurement in Lilburn cave, Kings Canyon National Park, California.

3. White WB (1988) Geomorphology and Hydrology of Karst Terrains. Oxford University Press, New York-Oxford, 464.

4. Ford DC, Williams PW (2007) Karst Hydrogeology and Geomorphology. John Wiley, Sons Ltd. 561.

5. Ford DC (1998) Perspectives in karst hydrogeology and cavern genesis. Bulletin d'Hydrogeologie 16: 9-29.

6. Williams PW (2008) The role of the epikarst in karst and cave hydrogeology: A review. International Journal of Speleology 37: 1-10.

7. Ford DC (1984) Karst groundwater activity and landform genesis in modern permafrost regions of Canada. In: LaFleur RG, Groundwater as a Geomorphic Agent. Allen\&Unwin, London, 340-350.

8. Veress M, Horváth ET, Zentai Z (1996) Egy magashegységi karsztterület vertikális karsztformáinak vizsgálata (Totes Gebirge, Ausztria) (The study of the vertical karst features of a high-mountain karst area) (Totes Gebirge) - A BDTF Tud. Közl. X. Természettudományok, Hungarian 5: 141-157.

9. Sárváry I (1970) A zsombolygenetika kérdéseiről (On the issues of shaft genetics) Karszt és Barlang I. 5-12.

10. Stegena L, Géczy B, Horváth F (1975) Late Cenozoic evolution of the Pannonian Basin. Tectonphysics 26: 71-90.

11. Budai T, Konrád Gy (2011) Magyarország földtana (Geology of Hungary). Pécsi Tudományegyetem, Pécs, 102.

12. Csontos L, Vörös A (2004) Mesozoic plate tectionic reconstruction of the Carpathian region. Paleogeography, Palaeoclimatology, Palaeoecology 210: 1-56.

13. Láng S (1962) A Bakony geomorfológiai vázlata (A geomorphological outline of the Bakony Mountains). Karszt és Barlangkutató Tájékoztató 7: 86-91.

14. Knauer J, Végh S (1965) A Bakony-hegység földtani térképe, 20000-es sorozat, Olaszfalu(A geological map of the Bakony Mountains, series 20000, Olaszfalu). Magyar Állami Földtani Intézet, Budapest, Hungarian.

15. Deák M (1972) Magyarázó Magyarország 200000-es földtani térképsorozatához (An interpretation to the 200000 geological map series of Hungary), L-33-XII. Veszprém - Magyar Állami Földtani Intézet, Budapest, Hungarian, 271.
16. Gyalog L (2005) Magyarázó Magyarország fedett földtani térképéhez (az egységek rövid leírása) 1:100000 (An interpretation to the 1:100000 covered geological map of Hungary, a short description of the units)-Magyar Állami Földtani Intézet Budapest, Hungarian 189.

17. Raincsák E (1980) A Várpalota - Iszkaszentgyörgy közötti triász vonulat szerkezete és felépítése (The Structure of the Triassic Ridge between Várpalota and Iskaszentgyörgy). Földtani Intézet Évi Jelentése 1978-ról, Budapest, Hungarian, 187-196.

18. Konda J (1970) A Bakony hegységi Júra időszaki képződmények üledékföldtani vizsgálata (Lithologishe und Fazies-Untersuchung der Jura-Ablagerungen des Bakony-Gebirges). Ann Inst Geol Publ Hung 50: 161-260.

19. Noszky J (1964) A Bakony-hegység északi részének földtani vizsgálata (A Geological Investigation of the northern part of the Bakony Mountains). Földtani Intézet Évi Jelentése 1961-ről, Budapest, Hungaria, 1: 203-206.

20. Bulla B (1968) A magyar föld domborzata fejlődésének ritmusai, az újharmadkor óta a korszerű geomorfológiai szemlélet megvilágításában (The phases of the Terrain Development of Hungary since the Lower Tertiary in perspective of the modern geomorphological view). Válogatott természeti földrajzi tanulmányok, Akadémia Kiadó, Budapest, Hungarian, 90-104.

21. Korpás L (1981) A Dunántúli-középhegység oligocén-alsó-miocén képződményei (Oligocene-Lower Miocene Formations of the Transdanubian Central Mountains in Hungary). MÁFI Évkönyve, Budapest, Hungarian, 140.

22. Pécsi M (1980) A Pannóniai-medence morfogenetikája (The Morphogenetics of the Pannonian Basin). Földr Ért, Hungarian, XXIX, 105-127.

23. Veress $M$ (2000) Covered karst evolution Northern Bakony mountains, W-Hungary. A Bakony Természettud. Kut. Eredményei, 23, Bakonyi Természettudományi Múzeum, Zirc, 167.

24. Jugovics L (1954) A Déli-Bakony és a Balaton-felvidék bazaltterületei (Basalt terrains of Southern Bakony and of Balaton Upland). Földtani Intézet Évi Jelentése, Budapest, Hungarian, 1953: 65-88.

25. Gvozdetskiy NA (1965) Types of Karst in the USSR Separatum, Prob Speleol Res, Prague, 47-54.

26. Hevesi A (1986) Hideg vizek létrehozta karsztok osztályozása (Classification of cold-water karsts). Földr Ért, Hungarian XXXV: 231-254.

27. Móga J, Németh R (2005) The morphological research of the basalt and loess covered plateaus in the Bakony Mts. (Transdanubian middle mts.-Hungary). Acta Carsologica 34: 397414.

28. Veress M, Unger Z (2015) Kab Mountain: Karst Under a Basalt Cap. In: Lóczy D, Landscapes and Landforms of Hungary. Springer, Heidelberg, New York, Dordrent, London, 55-62.

29. Veress M (2016) Covered Karst. Springer, Berlin, Heidelberg, New York, 536.

30. Veress M (2005) Adalékok a Tábla-völgyi-dülő (Tési-fennsík) fedett karsztosodásához (Data on covered karstification of the doline in Tábla valley, Tési plateau). Karsztfejlődés, Hungarian, X: 267-291.

31. Veress M (2006) Adatok a Tési-fennsík két térszínrészletének fedett karsztosodásához (Data on covered karstification of two 
Citation: Veress M (2019) Shaft Lengths and Shaft Development Types in the Vadose Zone of the Bakony Region (Transdanubian Mountains, Hungary). J Soil Water Sci 3(1):54-74

surface parts of the Tési plateau). Karsztfejlődés, Hungarian, XI: 171-184.

32. Veress M, Puskás J (2007) Adalékok az Eleven-Förtési töbörcsoport (Bakony-hegység) karsztosodásához (Contributions to the karstification of the Eleven. Förtes doline group, Bakony Mountains). Karsztfejlődés, Hungarian, XII: 171-192.

33. Papp $F$ (1941) Dunántúl karsztvizei és a feltárás lehetőségei Budapesten (The karst waters of Transdanubia and the opportunity of exploration). Hidrológiai Közlöny, Hungarian, 21: 146-196.

34. Szádeczky-Kardoss E (1941) A Dunántúli középhegység karsztvízének néhány problémájáról (On some problems of the karst water of the Transdanubian Mountains). Hidrológiai Közlöny, Hungarian 2: 67-92.

35. Szádeczky-Karrdos E (1948) A Dunántúli-középhegység karsztvíz térképe (The map of karstwater in the Transdanubian Mountains). Hidrológiai Közlöny, Hungarian, 28: 2-3.

36. Böcker $T$, Liebe $P$, Lorberer A, et al. (1982) A Dunántúli középhegység karsztvízszint térképe (The karst water level map of the Transdanubian Mountains). Vízgazdálkodási Tudományos Központ, Budapest, Hungarian.

37. Csepregi A (2007) A karsztvíz kiemelés hatása a Dunántúli-középhegység vízháztartására (The effect of karst water extraction on the water balance of the Transdanubian Mountains). In: Alföldi A, Kapolyi L (szerk.), Bányászati karsztvízszint süllyesztés a Dunántúli-középhegységben, MTA, Földrajztudományi Kutatóintézete, Hungarian, 77-112.

38. Böcker T (1972) A karsztvizek mozgásviszonyai természetes körülmények között (Karstwater movements under natural conditions). In: Szádeczky-Kardoss E, II. Anyag- és energiaáramlási ankét. Akadémia Kiadó, Budapest, Hungarian, 107-121.

39. Eszterhás I (1983) Az Alba Regia barlang a Bakony legnagyobb ismert barlangja (Alba Regia cave, the largest known cave of the Bakony Mountains). A Bakonyi Természettudományi Múzeum Közleményei, Hungarian, 2: 7-28.

40. Kárpát J (1981) Újabb feltárások a Bakonyban (Newer explorations in the Bakony Mountains). Karszt és Barlang, Hungarian, I-II: 56-57.

41. Kárpát J (1982) Alba Regia barlang (The Alba Regia cave).Magyarország barlangtérképei 22, Magyar Karszt- és Barlangkutató Társulat, Budapest, Hungarian.

42. Szilaj R (2014) Kessler Hubert-barlang (Kessler Hubert cave). In: Sliz Gy (szerk.), Felfedezések a föld alatt. Magyarország új barlangjai 2003-2013. Szent Özséb Barlangkutató Egyesület, Budapest, Hungarian, 16-19.

43. http://www.termeszetvedelem.hu/index.php?pg=caves\&mode $=$ search \&name $=\&$ katszam $=2892 \&$ city $=\&$ hrsz $=\&$ length comp $=$ al\&length $=0 \&$ vertkit_comp $=a \mid \&$ vertkit=0\&depth_com$\mathrm{p}=\mathrm{al} \&$ depth $=0$ \&height_comp $=$ al\&height $=0$ \& protection $=0 \&$ visit ing $=0$ \&orderby $=$ name \& direction $=$ asc\&headers $=50$

44. Kálmán Gy, Pethő J (1950) Úrkút és Ajka környékének részletes karsztvíz térképe (A detailed karst water map of the environs of Úrkút and Ajka). Hidrológiai Közlöny, XXX, Hungarian, 1-2: 175-178.

45. Bretz JH (1942) Vadose and Phreatic features of limestone caverns. Journal of Geology 50: 675-811.
46. Renault Ph (1968) Contribution à l'étude des action mécanique et sédimentologiques dans la spéléogenèse. Annales de spéléologie 23: 529-596.

47. Ford DC, Ewers RO (1978) The development of limestone cave systems in the dimensions of length and depth. Canadian Journal of Earth Sciences 15: 1783-1798.

48. Lauritzen SE, Lauritsen A (1995) Differential diagnosis of paragenetic and vadose canyons. Cave and Karst Science 21: 55-59.

49. Ford DC (2000) Speleogenesis Under Unconfined Setting. In: Klimchouk AB, Ford DC, Palmer AN, Dreybrodt W, Speleogenesis: Evolution of Karst Aquifers. National Speleological Society, Huntsville, Alabama, 319-324.

50. Farrant A (2004) Paragenesis. In: Gunn J, Encyclopedia of Caves and Karst Science. Fitzroy Dearborn, New York, London, 569-571.

51. Skoglund RO, Lauritzen SE (2010) Morphology and speleogenesis of Okshola, Fauske, northern Norway: example of a multi-stage network cave in a glacial landscape. Norwegian Journal of Geology, 90: 123-139.

52. Farrant AR, Simms MJ (2011) Ogof Draenen: speleogenesis of a hydrological see-saw from the karst of South Wales. Cave and Karst Science 38: 31-52.

53. Farrant AR, Smart PL (2011) Role of sediment in speleogenesis; sedimentation and paragenesis. Geomorphology 134: 79-93.

54. Pasini G (2009) Terminology matter: Paragenesis, antigravitátive erosion or antigravitational erosion?. International Journal of Speleology 38: 129-138.

55. Slabe T (1995) Cave Rocky Relief. Znanstvenaraziskovalni Center Sazu, Ljubljana, 128.

56. Bočič N, Faivre S, Kovacic M, et al. (2012) Cave development under the influence of Pleistocene glaciation in the Dinarides - an example from Štirovača Ice Cave (Velebit Mt., Croatia). Zeitschrift für Geomorphologie 56: 409-433.

57. Bretz JH (1956) Caves of Missouri. Geological Survey and Water Resources, Rolla, Missouri, 2: 491.

58. Bögli A (1978) Die wichtigsten Karrenformen der Kalkalpen. Karst processes and relevant landforms. International Speleological Union, Commission on Karst denudation. Department of Geography, Philosophical Faculty, University of Ljubljana, Ljubljana, 141-149.

59. Veress M (1987) Karsztos mélyedések múködése bakonyi fedett karsztokon (Activity of karst depressions on the covered karst in the Bakony Mountains). Földrajzi Értesítő, Hungarian 36: 91-114.

60. Veress M (1982) Adatok a Hárskúti-fennsík morfogenetikájához (Data on the morphogenesis of the Hárskút Plateau). Karszt Barlang, Hungarian, I: 71-82.

61. Takácsné Bolner K (2006) Morfogenetikai megfigyelések a Njegusi polje (Montenegro) nagy barlangjaiban (Morphogenetic observations in the large caves of Njegusi Polje, Montenegro). Karsztfejlődés XI: 289-300 (in Hungarian).

62. Ford DC (1979) A review of alpine karst in the Southern Rocky Mountains of Canada. Bull Nat Speleol Soc 41: 53-65.

63. Veress M, Telbisz T, Tóth G, et al. (2015) Glaciokarsts. Springer: Cham, Switzerland, 516.

DOI: $10.36959 / 624 / 431$

Copyright: (C) 2019 Veress M. This is an open-access article distributed under the terms of the Creative Commons Attribution License, which permits unrestricted use, distribution, and reproduction in any medium, provided the original author and source are credited.

SCHOLARS.DiRECT 